\title{
The Place of Religion in Human Rights Law: Distinguishing Freedom of Religion from the Right against Religious Discrimination
}

- Tarunabh Khaitan and Jane Calderwood Norton*

\begin{abstract}
:
This paper argues that, while they are often conflated, the right to freedom of religion and the right against religious discrimination are in fact distinct human rights. Religious freedom is best understood as protecting our interest in religious adherence (and non-adherence), understood from the committed perspective of the (non)adherent. The right against religious discrimination is best understood as protecting our non-committal interest in the unsaddled membership of our religious group. Thus understood, the two rights have distinct normative rationales. Key doctrinal implications follow for the respective scope of the two rights, whether they may be claimed against non-state actors, and their divergent assessment of religious establishment. These differences reveal a complex map of two overlapping, but conceptually distinct, human rights which are not necessarily breached simultaneously.
\end{abstract}

\section{Introduction}

We live in a post-secular world where religion has made a surprising comeback, falsifying Weberian predictions of ever-continuing secularization. ${ }^{1}$ Almost every large society-some for the first time in recent history - is grappling with religious pluralism. At the same time, however, religious conflicts and religious terrorism occupy newspaper headlines, Islamophobia has become rampant, ${ }^{2}$ anti-Semitism has increased, and lower-scale religious hostility is rife. Even majority religions now view themselves as victims of secularization, multiculturalism, and the feminist and gay rights 'agendas'. The re-emergence of religion has resulted in at least some of these issues being debated in courts, using the legally prescribed discourse of human rights. Here, we most commonly see this debate through the right to religious freedom or the right against religious discrimination.

This article is an intervention in an ongoing debate around the legal protection for religion. Some argue that the prohibition on religious discrimination has become a tool to protect prejudice and intolerance (usually against women, gays, bisexuals, lesbians and transpersons), and therefore religion should lose its status as a protected characteristic altogether. ${ }^{3}$ By contrast, others argue that discrimination law is not taking conscience-based claims of religious adherents seriously enough and, in its zeal to protect gay people from discrimination, is itself

\footnotetext{
* Tarunabh Khaitan is an Associate Professor in Law at Wadham College, Oxford and Melbourne Law School. Jane Norton is a Senior Lecturer at the University of Auckland law faculty. We thank David Richards, Ayelet Schachar, Andrew Koppelman, Stéphanie Hennette-Vauchez, Stijn Smet, Reva Siegel, Bridget Arimond, Richard Stacey, Colin Campbell, Richard Moon, Sam Bagenstos, Ashleigh Keall, Ronan McCrea, Eugenio Arguelles, Joseph Weiler, Jianlin Chen, Matthew Lewans, Dale Smith, Mark Bell and Christopher McCrudden. Special thanks to Sati Nagra for research support. Usual disclaimers apply.

${ }^{1}$ Peter Berger, The Many Altars of Modernity: Towards a Paradigm for Religion in a Pluralist Age (2014); Suzanne Mancini \& Michel Rosenfeld, Constitutional Secularism in an Age of Religious Revival, at XV-xvi (Mancini \& Rosenfeld eds., 2014) (referring to the 'repoliticization of religion'). For an analysis as to the different strands of secularism see CÉCILE LABORDE, LIBERALISM’s RELIGION (2017).

${ }^{2}$ We find 'islamophobia' an inadequate term for capturing prejudice against Muslims, but are sticking to it because it has acquired a certain currency.

${ }^{3}$ Aileen McColgan, Class Wars? Religion and (In)equality in the Workplace, 38 INDUS. L. J. 1 (2009).
} 
discriminating against religious people, alongside violating their religious freedom. ${ }^{4}$ As such, this argument goes, human rights protection of religion is becoming increasingly toothless. It seems that neither side is happy with how the law deals with religion.

This paper approaches the debate around law and religion from a different angle by arguing that, while they are often conflated, the right to freedom of religion and the right against religious discrimination are in fact distinct human rights. As such, they protect distinct human interests and distinct (although often overlapping) aspects of religion. Religious freedom is best understood as protecting our interest in religious (non)adherence. The right against religious discrimination is best understood as protecting our interest in the unsaddled membership of our religious group. ${ }^{5}$ One right is interested in protecting certain beliefs and practices, the other in protecting our tribe. The distinction is well-captured in the old joke about a Belfast rabbi being asked if he was 'a Protestant Jew or a Catholic Jew'. Or, as Ashis Nandy claimed in the Indian context, 'Hindutva will be the end of Hinduism' ${ }^{6}$ In these examples, Protestantism/Catholicism/Hindutva identify socio-political group identities, whereas Judaism and Hinduism concern religious adherence. And yet, legal scholarship has paid little attention to this distinction or to its implications. ${ }^{7}$ This paper sets out the distinction between the two sets of interests and their corresponding rights in conceptually clear terms, outlines the normative and doctrinal implications that follow, and warns against the normative and practical dangers of confusing the two sets of rights and interests.

Section 2 identifies and explains these two distinct religious interests. These interests may be distinguished by adopting different perspectives: religion as viewed from the committed perspective of the (non)adherent on the one hand and, on the other hand, the privileges and disadvantages that accompany the membership of a religious group as assessed from the noncommittal (public) point of view. This distinction is important for two reasons. First, unpacking the differing facets of religious interests provides theoretical clarification-what is the law protecting when it protects religion? Secondly, the distinction has practical implications for how religious interests are protected. Section 3 identifies a key conceptual distinction between the two religious interests distinguished in the preceding section: religious adherence tracks the freedom to pursue the good, whereas unsaddled membership of a religious group directly tracks the good. In Section 4, we argue that the right to religious freedom is best understood as protecting our interest in religious (non)adherence, whereas the right against religious discrimination is best understood as protecting religious group membership. We further argue that the value of respecting decisional autonomy in matters of religious adherence underpins religious freedom, whereas the need to reduce the socio-cultural and material advantage gaps between different religious groups is the key aim of the right against religious discrimination.

This distinction between religious adherence and religious group membership can help explain why it is not inconsistent for a person to disapprove of a religious group being made a target

\footnotetext{
${ }^{4}$ Christopher McCrudden, Marriage Registrars, Same-Sex Relationships, and Religious Discrimination in the European Court of Human Rights (Queen's U. Belfast L. Res. Paper No. 2812289, July 2016), https://papers.ssrn.com/sol3/papers.cfm?abstract_id=2812289.

${ }^{5}$ By 'unsaddled' membership we mean membership that does not incur external social, economic, cultural or political costs. Religious adherence often demands compliance with the internal rules of the religion. That group members who are also adherents of that religion will be 'saddled' with these internal rules is not of concern here. ${ }^{6}$ Ashis Nandy, The Twilight of Certitudes: Secularism, Hindu Nationalism and Other Masks of Deculturation, 1 POSTCOLONIAL STUD., 283, 294 (1998).

${ }^{7}$ Honorable exceptions include Ronan McRea, Squaring the Circle: Can an Egalitarian and Individualistic Conception of Freedom of Religion or Belief Co-Exist with the Notion of Indirect Discrimination?, in Foundations OF INDIRECT Discrimination LAW (Hugh Collins \& Tarunabh Khaitan eds., 2018); McCrudden, supra note 4.
} 
of prejudice, stereotypes and social disadvantage, while at the same time rejecting or even condemning, some of the substantive religious beliefs of some such groups. It also explains why an uncommitted/non-adherent person can and should still receive antidiscrimination law's protection. The conceptual distinction we are proposing may not always be observed in the practice of a given jurisdiction. Lawyers often have strategic reasons to throw whatever argument might stick, and conceptual tidiness is often a casualty. It would be naive to expect theory and practice to mirror each other. Nonetheless, the conceptual (and normative) claims in this paper should be a useful guide to understanding the two rights that concern religion.

Finally, Section 5 highlights key practical implications of this distinction. In particular, we discuss the differences between the scope of the two rights, the possibility of their horizontal application, difference in attitude to non-zero-sum benefits, and areas of overlap and distinction between the two rights. We argue that the scope of religious freedom is extremely broad, whereas that of religious antidiscrimination is relatively narrow. On the other hand, there are good reasons why religious freedom should be restricted as a claim solely against the state, whereas a claim of religious discrimination may be permitted against certain non-state actors as well. We demonstrate that certain forms of religious establishment, and other non-zero-sum benefits to particular religious groups, breach the antidiscrimination guarantee but not the religious freedom guarantee. Finally, we map the areas of overlap between the two rights, and identify cases where one of these rights is engaged but not the other.

\section{Two Distinct Religious Interests, from the Committed and Non-Committal Perspectives}

In this section, we identify two distinct interests we have with respect to religion: an interest in religious (non)adherence and an interest in our ability to enjoy unsaddled membership of a religious group. To explore this distinction further, we distinguish the committed perspective of the religious (non)adherent from the non-committal (public) identification of the privileges and disadvantages - social, economic, cultural and political - that accompany the membership of (different) religious groups. The distinction grounds subsequent discussion about the nature of the two human rights concerning religion.

A word first about what is meant by religion. Religion is a complex and multifaceted intersubjective phenomenon, in the sense that its existence depends on its shared acceptance in the consciousness of several persons. Not all details of its contents need to be shared, but as a 'social form', ${ }^{8}$ it cannot exist outside of some shared consciousness within a social group. Other similar intersubjective phenomena include marriage (it will be meaningless to 'marry' someone in a society where it did not exist as a social form), money (few would trade valuable goods for pieces of paper without an intersubjective acceptance of the value of these pieces of paper) and nations (imagined communities they might be, ${ }^{9}$ but a nation cannot be constituted in the imagination of one person - or, even ten, for that matter). This intersubjectivity requirement qualifies the committed perspective we are about to explore-it places constraints on what can count as religion, and more importantly what cannot (for example, my personal cult of bunny

\footnotetext{
8 Joseph RaZ, The Morality of FreEDOM 308-310 (1986). Raz understands social forms to be 'forms of behaviour which are... widely practised in society' or 'common social forms of action'. Social forms have 'internal richness and complexity' and the degree to which a practice has to be shared, and by whom, are open questions. Raz is clear, however, that comprehensive personal goals - such as, on our argument, religious (non)adherencecan only be founded in social forms. We assume, without argument, that atheism is a social form in most contemporary societies, although this is likely to be the case for many societies in the past too.

9 Benedict Anderson, Imagined Communities: Reflections on the Origin AND SpREAd of NATIONALiSM (1983).
} 
worship is not likely to satisfy the intersubjectivity requirement).$^{10}$ Intersubjectivity, of course, admits to degrees - perhaps the traditional distinction between a religion and a cult (sans its more recent negative connotations) was based on the notion that cults are putative religions that do not (yet) satisfy the intersubjectivity threshold.

Beyond this, it is notoriously difficult, and potentially problematic, to define religion. ${ }^{11} \mathrm{We}$ will not attempt to do what our betters have been unable to do. Instead, we will satisfy ourselves with identifying the two distinct interests that people have in matters concerning religion: an interest in religious (non)adherence and an interest in the unsaddled membership of a religious group.

\subsection{The Committed Interest in Religious (Non)Adherence}

The committed or internal point of view is the point of view of the religious adherent. An adherent strives to believe in (what she thinks are) the tenets of her religion, and tries to practise (what in her view) it demands of her. From the committed perspective, in other words, religious adherence involves a commitment to some combination of a set of beliefs and practices. Our interest here is to briefly describe the phenomenon of religious adherence (and non-adherence) as it actually exists in most democracies. This must be the starting point of any account that seeks to understand the nature of our interest in religious (non)adherence. As such, we deliberately privilege this descriptive account of the committed adherent's perspective over any official doctrinal perspective of an authoritative religious body. In religions that have authoritative bodies - such as hierarchical churches - the official perspective of these bodies may well be reflected in that of many of its adherents. But adopting the official doctrinal perspective would be contrary to our goal of drawing up a capacious picture of religious (non)adherence that reflects the diversity between, and within, religions. ${ }^{12}$

Before we proceed, two points on the prefix 'non' before 'adherents'. First, non-adhering belief and practice are important not only to atheists and agnostics, but to all religious adherents. This is because adherents of a given religious tradition usually do so exclusively. In other words, their adherence to religion $\mathrm{X}$ often entails a rejection of all other religions, including (say) $\mathrm{Y}$. Non-adherence is not restricted to matters of belief. Sometimes it demands performative nonparticipation in rituals or worship of other religions. Therefore, to take the committed perspective seriously we must recognize that for the adherent of $\mathrm{X}$, it may be important (for her adherence to X) not to believe in, or perform acts that are based on, the tenets of religion Y. For example, it may be important for an atheist or Jewish witness not to swear on the Christian Bible. Even in cases where the demands of another's religion entail an omission rather than an action - for example, non-Hindus required to refrain from eating beef-an interest in religious non-adherence is engaged if the prohibition on beef-eating was premised on the Hindu injunction to treat the cow as sacred. In other words, all of us have an interest in religious non-adherence, whether we choose to assert it or not. More importantly, perhaps, non-

\footnotetext{
${ }^{10}$ Maclure and Taylor, among others, also distinguish between 'religious beliefs' and 'expensive tastes', but on criteria other than intersubjectivity: see Jocelyn MACluRE \& CHARLES TAYLOR, SECUlARISM AND FREEDOM OF CONSCIENCE 76 (2011).

${ }^{11}$ See George C. Freeman, III, The Misguided Search for the Constitutional Definition of "Religion", 71 Geo. L.J. 1519 (1983). See also CARolyn Evans, Freedom of Religion under the European CONVENTION ON Human Rights 51 (2001); Kent Greenawalt, Religion as a Concept in Constitutional Law, 72 CAL. L. Rev. 753 (1984); R (Williamson) v. Secretary of State for Education and Employment [2005] 2 AC 246 (HL) at [57]-[58]. ${ }^{12}$ See Volkhard Krech et al., Religious Diversity and Religious Vitality: New Measuring Strategies and Empirical Evidence, 9 InTERDISC. J. OF ReS. ON RELIGION 2 (2013); Lars Ahlin et al., Religious Diversity and Pluralism: Empirical Data and Theoretical Reflections from the Danish Pluralism Project, 27 J. OF ConTEMP. Religion 403-418 (2012); Detlef Pollack, Religious Pluralism: Undermining or Reinforcing Religiosity?, 53 SOCIETY 131136 (2016).
} 
adherence can, and usually does, arise out of religious commitment to the extent that adherence (to religion $\mathrm{X}$ ) usually entails non-adherence (to religion $\mathrm{Y}$ ).

The second point regarding non-adherence is that the line between the religious and the atheist is often drawn too sharply. In reality, not only are some religions atheistic (e.g. Jainism) or agnostic (e.g. some versions of Buddhism), others include the acceptance as well as the rejection of the divine within their ambit (e.g. Hinduism). ${ }^{13}$ Given the numerous ways in which religiosity manifests itself (consider, for example, those atheists who describe themselves as 'spiritual'), sharp divisions between atheism and religiosity may capture the reality for some people, but unlikely to do so for everyone. ${ }^{14}$ For these reasons, our interest in religious adherence must be understood to include an interest in non-adherence (jointly referred to as (non)adherence).

We can now turn to the first dimension of religious (non)adherence. The dimension of belief, or as the European Court of Human Rights prefers to call it, the forum internum, entails (not) subscribing to certain fundamental beliefs (usually, but not necessarily) concerning the nature, origin and character of life, especially focussing on the human condition and usually entailing views about improving it. This can include metaphysical views on life, pre-life, afterlife, and future lives, and the nature and existence of superhuman or non-human beings or powers as well as human ancestors. This is broadly consistent with what the UK Supreme Court recently referred to as 'mankind's place in the universe and relationship with the infinite ... [which] may or may not involve belief in a supreme being. ${ }^{15}$ Characterizing this dimension of religion broadly in terms of 'belief', rather than narrowly as 'faith', allows religious traditions that invite belief without demanding faith to be included in the concept. It also encompasses those beliefs concerning god(s) and religion that are indifferent to, or even reject, faith or god (including versions of Buddhism, Jainism, atheism and agnosticism).

Given this characterization of belief, one objection to our account of the committed perspective on religion might be that it is unrealistic, or, at least, not true for many adherents. The term 'belief' can be read to overplay the thoughtfulness, consideration and intensity that go into religious adherence. Many people simply (one may say, unthinkingly) follow the (non)religion of their parents. ${ }^{16}$ Many others have a relaxed rather than intense, and flexible rather than dogmatic, approach to religious (non)adherence. Given our commitment to imbuing our conception of religious (non)adherence with the capaciousness that exists in practice, it would be odd if it included only the intense, inflexible, thoughtful or single-minded (non)adherent. ${ }^{17}$ While our characterization of belief may not hold true for everyone, we take the seriousness and thoughtfulness that go into religious belief as a potentiality - realized to different degrees by different (non)adherents.

This potential for seriousness and thoughtfulness exists in those who reject religious adherence as much as in those who accept it. Some Christians rarely think about their Christianity, others arrive at it through deep contemplation, after rejecting the alternatives. Similarly, for some atheists, their atheism is merely a default (absence of) belief. For others, on the other hand,

${ }^{13}$ See generally Linda Woodhead, Intensified Religious Pluralism and De-differentiation: The British Example, 53 Society 41 (2016). See also Amartya Sen, The Argumentative Indian: Writings On Indian History, CULTURE AND IDENTITY 46 (2006) (Sen's recollection of a conversation with his grandfather, who identified the former's atheism as falling in the 'Lokayata part of the Hindu spectrum').

${ }^{14}$ See Ronald Dworkin, Religion without God (2013).

${ }^{15}$ R (Hodkin) v. Registrar General of Births, Deaths and Marriages [2013] UKSC 77 [57], [2014] AC 610 [57].

${ }^{16}$ See Farrah Ahmed, The Autonomy Rationale for Religious Freedom, 80 MoD. L. REV. 238 (2017).

${ }_{17}$ On a sociological index used to measure intensity of religiosity in persons, see Stefan Huber \& Odilo Huber, The Centrality of Religiosity Scale, 3 RELIGIONS 710-724 (2012). 
rejection of all (or some) religions is a deeply considered, strongly held, metaphysical and ethical belief fundamental to their individuality-some atheists are quite devout in their unbelief. The point is this: in the dimension of belief, religions make claims which have truth value (i.e. they are the sort of claims that may be true or false, or be true to some extent). This is why adherents are able to accept these claims are true. ${ }^{18}$ Accepting or rejecting these claims can both be thoughtful or thoughtless, salient or unimportant, intense or relaxed.

Despite these objections, we defend this capacious conception of religious belief, which adopts the committed (but not necessarily dogmatic) perspective of the adherent, because it most truly reflects the diversity of religious belief that exists.

The second dimension of religion, from the adherent's viewpoint, is its practical or performative side - its forum externum. This usually entails rules of behavior and performative practices such as worship, prayer, sacrifice, rituals, and meditation. The scope and demandingness of religious practice varies from religion to religion. Some religions also require that at least some of these practices and rituals must be undertaken in community with other adherents. Indeed, some practices and rituals can only take place where there is a religious community. ${ }^{19}$ Thus, the committed viewpoint often has a communal dimension. Some practical dimensions of religion follow from beliefs, often called manifestations of beliefs in European law, and provide reasons for action. But not all religious practice and performance can be characterized as manifestations of beliefs. Some religions (like Protestantism) emphasise beliefs, others (such as Buddhism and Orthodox Judaism) focus on practice, most on some combination of the two. ${ }^{20}$

We have seen how religious commitment is diverse. When we take the diversity of religious commitment seriously, we notice that most adherents subscribe to a web of multiple, but usually interrelated, beliefs and practices. Viewed from this committed perspective, the level of religious diversity one finds around the world is astonishing. Some religions seek coherence in their package of beliefs and practices. Others, like Hinduism, are happier to embrace mutually contradictory beliefs and practices. Even when not directly contradictory, there is significant interpretive latitude around religious demands on adherents. ${ }^{21}$ Even in religions with internal structures that make authoritative rulings on doctrinal disagreements, adherents often pick and choose from the packages on offer-the diversity of beliefs among Catholics on the legitimacy of same-sex marriages and abortion is a case in point. ${ }^{22}$ Indeed, a recent sociological study of 'Catholics' in the UK shows that 'if we measure Catholics by their conformity to some of the key beliefs and behaviors laid down by the Catholic magisterium ... only $5 \%$ of Catholics qualify as "faithful" or orthodox' ${ }^{23}$ Further still, adherents are often capable of giving varying weights and emphases to different religious demands, making the actual practice of religion

\footnotetext{
18 See Paul Horwitz, The Agnostic Age: Law, Religion, and the Constitution 153-4 (2011).

19 See Farrah Ahmed \& Jane Calderwood Norton, Religious Tribunals, Religious Freedom, and Concern for Vulnerable Woman, 24 CHILD \& FAM. L. Q. 363, 377-378 (2012).

${ }^{20}$ It is for this reason that we use the capacious term 'adherent' rather than the narrower term 'believer' to describe a person committed to a religion.

${ }^{21}$ This is why talk of Catholicisms, Islams and Judaisms makes sense: Peter W. Edge, Determining Religion in English Courts, 1 Oxf. J. OF L. AND Religion 402, at 402, 406 (2012); FARraH AHMED, ReLigious FreEdom UNDER THE PERSONAL LAW SySTEM 19-21 (2016).

22 Ayelet Shachar discusses this selectivity_or 'forum shopping' - between state and religious institutions in the context of family law disputes: see AYELET SHACHAR, MULTICULTURAL JURISDICTIONS: CULTURAL DifFERENCES AND WOMEN'S Rights 122-126 (2001). John Bowen observed similar selectivity in relation to shari'a law in England: John Bowden, Private Arrangements "Recognizing Sharia" in England, Boston ReVIEW (March/April 2009), www.http://bostonreview.net/BR34.2/bowen.php.

${ }^{23}$ Woodhead, supra note 13 , at 42.
} 
staggeringly pluralistic. As the history of religious conflicts has shown, these differences could be over relatively small, and-for non-adherents and even some adherents of the same religion-inconsequential matters.

The committed interest in religious (non)adherence is expansive. It presents a picture of religious (non)adherence that is diverse and pluralistic (both within and between religions). This diversity exists in the dimensions of belief and practice. Religious commitment demands adherence as well as non-adherence from us. These expansive takes on our interest in (non)adherence are tempered, however, by the requirement of intersubjectivity. Intersubjectivity filters out highly eccentric and frivolous beliefs or practices. As such, the committed perspective avoids three potential pitfalls when defining the scope of the interest in religious (non)adherence: (i) over-inclusion that leads to the protection of just about any ideology, belief or practice, (ii) under-inclusion of dissenting, minority, and heterodox religions, and (iii) exclusion of atheism and agnosticism. ${ }^{24}$ These findings are central to how we understand the right to freedom of religion, and the values that underpin it.

\subsection{The Non-Committal Interest in Unsaddled Membership of a Religious Group}

Having considered religion from the committed perspective of the adherent, we now consider the phenomenon from a different angle by adopting an external or public perspective. This can be termed the non-committal perspective. From the non-committal, or public, perspective, we focus not on adherents of certain religions but on members of certain religious groups.

Group membership can affect how power and advantage are distributed in society. In most human societies, power and advantage — material, socio-cultural, political—are distributed in ways are that sensitive to certain personal characteristics (such as race, educational attainment, or gender) but insensitive to other personal characteristics (such as zodiac signs, the number of letters in one's name, or one's favourite colour). ${ }^{25}$ Individual exceptions no doubt abound, but on a macro-level, these claims are generally accepted as true of many contemporary societies. Religious group membership, in most societies, tends to fall in the former category, inasmuch as it tends to affect the success of our lives (at least in the material world). Here, it does not matter whether a person actually adheres to the beliefs or practices of any particular religion. She is more likely than not to have the powers and advantages (or lack thereof) in keeping with others who are, or are perceived to be, the members of the same religious group. She may belong to (or be perceived to belong to) a religious group, even without being an adherent. This (assumption of) membership may be because of the religious group membership of her parents, or because religious practice has become a familiar part of her cultural habits, or because she carries proxy characteristics (such as belonging to certain racial or ethnic groups) that signify (to others) adherence to a particular religion. She may even take pride in her membership of her religious group and find community and solace in fellow members despite not being an adherent, or she may dislike it, or be indifferent to it. Just like her membership of her caste or racial group, how she feels about it makes little difference to her actual or perceived religious group membership, just as her adherence or lack thereof makes no difference either. Like it or not, she is likely to be saddled with (or enjoy the privileges of) the (dis)advantages that accompany her membership of her religious group.

In most cases adherents are likely to be members of a religious group. However, the two categories do not entirely map onto each other. For example, recent converts may have cultural and ethnic traits that differ from most adherents. There are people who identify as 'cultural

\footnotetext{
${ }^{24}$ Andrew Koppelman, How Could Religious Liberty Be a Human Right? InT'L J. OF CONST. LAw (forthcoming), https://papers.ssrn.com/sol3/papers.cfm?abstract_id=2995605\#\#.

${ }^{25}$ See Tarunabh Khaitan, A Theory of Discrimination Law, ch. 2-3 (2015).
} 
Christians' or 'atheistic Jews' having given up on adherence but not on the associated cultural traits. Heterodox and dissenting interpreters of a tradition-such as Reform Jews and Ahmadis - may be saddled with the cultural identification of majority adherents by the outside world but seen as non-members, or even heretics, by their 'co-religionists'. It is not uncommon for Sikhs in North America and elsewhere to be taken to be Muslims because of racial and cultural similarities. These examples illustrate that (non)membership of a religious group is not always within the control of the individual.

The non-committal perspective takes seriously the fact that religious group membership often gets mixed up with culture, ethnicity, race, language, and nationalism. Not only is the (non)membership of her religious group not fully within the control of the individual adherent, she usually has even less control over the socio-political and material disabilities (or privileges) that accompany such membership. What is more, even for a typical religious adherent who fully embraces her actual and perceived religious group membership, her interest in being able to adhere truly to her religion is related to, but surely distinct from, her interest in her religious group not being subject to social, cultural, material or political disabilities.

Implicit in the preceding paragraphs is a very specific conception of a 'group'. The term is not necessarily used to refer to a cohesive collectivity with a shared culture/language/history/religion/identity etc. ${ }^{26}$ We have used the term 'group' more loosely. It includes people who perceive themselves to be members of the group even when the group does not and those who are taken to be the members of the group when they do not see themselves as such. There need not be any cohesiveness to this 'group'. On our understanding, 'people with disabilities', heterosexuals, and yes, even atheists, qualify as a group. Having said that, given the non-committal perspective we have assumed, there needs to be some external, sociological, reality to the group, outside of the internal point of view of its members. ${ }^{27}$

We have identified two interests pertaining to religion: the committed interest in religious (non) adherence and the non-committal interest in unsaddled membership of a religious group. These interests, we argue, are distinct. By way of illustration, a 'Muslim' woman, living in a deprived, predominantly Muslim, neighbourhood in Birmingham (or Delhi, for that matter) suffers because of such deprivation, whether or not she if fact adheres to any version of Islam. On the other hand, being forbidden from wearing a crucifix at work might engage a devout Christian's interest in religious adherence, but does not — in itself — affect his membership of his religious group (understood in the loose sense as explained above). We now turn to a key conceptual difference between these interests.

\section{A Conceptual Distinction between the Two Interests}

We have identified two distinct interests a person might have with respect to religion: (i) an interest in her ability to (intersubjectively) determine and to pursue her religious commitments as a (non)adherent, and (ii) an interest in being unsaddled by the disabilities that accompany her religious group membership. Religion is not unique in possessing these two dimensions. Pregnancy, for example, has an internal dimension concerning a person's decision (as well as her ability to decide whether) to become (or not become) pregnant. From the non-committal perspective, on the other hand, pregnancy (and the ability or potential to become pregnant) brings with it certain social and economic costs, such as reduced attractiveness in the employment market, the stigma attached to pregnancy outside marriage, the medical and care

\footnotetext{
${ }^{26}$ On this type of religious 'group', see Renate Ysseldyk et al., Religiosity as Identity: Toward an Understanding of Religion From a Social Identity Perspective, 14 Personality \& Soc. Psychol. ReV. 60, 60-71 (2010).

${ }^{27}$ See infra Section 5.1 Scope of the Rights (discussion towards the end of the section).
} 
costs associated with pregnancy and so on. Sexual orientation has a similar quality. From the internal point of view, what matters is a person's orientation with respect to the sex and gender of the person they are sexually or romantically attracted to, and their decision (as well as their ability to decide whether) to associate sexually and/or romantically with a person of the same sex as their own. Societally, this could have been completely irrelevant to the distribution of social, cultural, political and material power between gay people and heterosexuals; unfortunately, as we know, this is not the case.

Defenders of pregnancy and sexual orientation rights have questioned whether privacy or antidiscrimination is a better approach to defend these rights. ${ }^{28}$ These debates have taken place precisely because both approaches have something to offer to the protection of the interests involved. In this section, we draw upon these continuities to clarify a key conceptual distinction between the two categories of religious interests identified in the previous section. Unlike the debates that have taken place in the context of pregnancy and sexual orientation, however, we will show that these are not alternative ways of framing the same human interest, rather that they are two distinct interests that we ought to treat separately.

We draw a conceptual distinction between two sets of human interests: our interests in the good, and our interests in our freedom to pursue the good. In the first set, we have interests whose satisfaction is, at least prima facie, necessarily a good thing (from a public, objective, perspective). It may not be possible to always protect such interests all things considered, and some such compromises may be entirely legitimate. But on their own, the satisfaction of these interests is always a good thing. Such interests include our interest in adequate nutrition, good education, fair trial, protective shelter, and so on. In all these cases, the good is tracked directly by the satisfaction of the interest concerned.

On the other hand, we have interests not only in realizing the good, but also (or, even especially) in pursuing the good on our own. In these cases, it is in our interest to freely define the good and to pursue it, even when we might sometimes make mistakes. ${ }^{29}$ Examples include our interest in freely choosing who to become friends with, whether and who to marry, what and how to say something, what career to pursue, whether and what films to watch or books to read and so on. While, generally speaking, being free to pursue the good in such cases is a good thing, there is the possibility of making mistakes. Making friends with bullies, saying hurtful things simply to hurt others, or joining a racist organisation do not become good simply because these acts were freely done. For this reason, the distinction between interests that directly track the good and those that track my interest in the freedom to define and to pursue the good makes sense. ${ }^{30}$ We do not, lest we are misunderstood, wish to suggest that our interests in the good are necessarily superior to our interests in our freedom to pursue the good. They are, nonetheless, conceptually different, and this difference could be normatively salient.

Now we can map this distinction onto the two interests we have identified. It is always a good thing that one's religious group is not saddled with relative social, political and material disabilities. This is just a roundabout way of saying that social disabilities should not, in an ideal world, accompany religious group membership. On the other hand, our interest in

\footnotetext{
${ }^{28}$ See the Yoshino-Gerken debate: Heather Gerken, Larry and Lawrence, 42 TUlSA L. REV. 843 (2008); Kenji Yoshino, Tribe, 42 Tulsa L. Rev 961 (2008). See also David Richards, Liberal Democracy and the Problems of Patriarchy, 46 ISRAEL L. REV. 169 (2013).

${ }^{29}$ Analogous to these interests are the rights that include the 'right to do wrong': see Jeremy Waldron, $A$ Right to Do Wrong, 92 ETHICS 21 (1981).

${ }^{30}$ Posner draws a similar distinction between intermediate/instrumental goods on the one hand and final/ultimate goods on the other: see Richard Posner, The Right to Privacy, 12 GEORGIA L. REV. 393, 394 (1977).
} 
religious adherence tracks our freedom to pursue the good in matters religious. The intersubjectively determined committed viewpoint is not, after all, subject to any public standard of reasonableness or morality, and may therefore make demands that are unreasonable or immoral. This key conceptual distinction underpins some of the normative judgments that need to be made in relation to the protection of these interests, especially in relation to their operation in horizontal relations between non-state actors.

\section{The Right to Freedom of Religion and the Right Against Religious Discrimination}

Our starting point is that if most human rights documents recognize two distinct human rights pertaining to religion - the right to freedom of religion and the right against religious nondiscrimination - they are best understood as protecting distinct religious interests. The claim is conceptual and normative, rather than historical. Even if their distinct articulation is a historical accident, or even technical oversight on the part of the drafters, the conceptual claim would still be plausible in light of the distinctiveness of the two religious interests we identified in Section 2. Having identified these distinct interests, we will now argue that our interest in religious adherence is best protected under the right to freedom of religion, and we are most likely to enjoy unsaddled religious group membership under a robust right against religious discrimination.

The main reason for this claim is that there are structural similarities between the interests identified in Section 2 and the jurisprudence concerning the two rights (at least in Europe). While there are other ways of reading legal doctrine concerning these rights, we offer a normative restatement of these rights by selecting those strands in the jurisprudence that do the best job of protecting the two religious interests at stake. Thus, the interest and the right mutually define each other. We will argue that freedom of religion is valuable because it protects our decisional autonomy in matters of religious adherence. Freedom from discrimination based on certain protected characteristics matters morally because the possession of these characteristics tends to affect our access to those basic goods necessary for living a good life.

\subsection{The Right to Freedom of Religion}

Freedom of religion is valuable because it protects our decisional autonomy in matters of religious adherence. Many other foundational values are also plausible, including the value of social goods such as religious tolerance, religious pluralism and social harmony, and the value in respecting an individual's conscience or integrity. We do not deny that these values may also be good reasons to support some version of religious freedom. However, the only value that can fully support the capacious version of our interest in religious (non)adherence (as understood in Section 2) is the need to respect our decisional autonomy in matters pertaining to religious adherence.

Religious pluralism, harmony and tolerance are no doubt valuable social goods, but they fail to directly underpin an individual's interest in religious (non)adherence (even though many may indirectly facilitate its protection in most circumstances). The historical origins of the protection of religious freedom may well lie in these social goods. ${ }^{31}$ Since its transformation into a contemporary human right, however, its underlying rationale must, at least primarily, be found in a fundamental human interest, rather than in the common good. ${ }^{32}$

\footnotetext{
${ }^{31}$ See Douglas Laycock, Religious Liberty as Liberty, 7 J. OF CONTEMP. LEGAL ISSUES 313, 317 (1996).

${ }^{32} \mathrm{R}$ (Williamson) v. Secretary of State for Education and Employment [2005] 2 AC 246 (HL) at [22] (freedom of religion protects the subjective belief of an individual).
} 
The need to respect an individual's conscience is a more promising candidate. In fact, some scholars believe that religion is merely a placeholder for the protection of 'conscience' in human rights law. ${ }^{33}$ While there might be very good reasons to protect conscience for its own sake, our account of religious adherence from the committed viewpoint shows that religion is both broader and narrower than conscience. Not all religious beliefs implicate one's conscience, which is typically other-regarding rather than self-regarding. For example, most people would accept that the religious obligations of Muslims to pray five times a day or make a pilgrimage are not matters of conscience. A belief that does not engage one's conscience may nonetheless be fundamentally important to the believer because it is demanded by his or her religion. On the other hand, not all conscientious beliefs are 'religious'. While many systemic and comprehensive worldviews, such as pacifism and environmentalism, could be sufficiently religion-like for certain purposes (and should perhaps be treated as such by human rights law), one's conscience can also make standalone demands against military service or eating animal products that do not flow from an existing commitment to any broader worldview or involve intersubjectivity. For these reasons, the value of respecting an individual's conscience cannot ground the right to religious freedom.

Personal integrity is also insufficient to ground the right to religious freedom. This value takes an individual's relationship to herself seriously, and facilitates a harmonious and complete conception of one's self. It is related to conscience, but can encompass not only ethical, but also performative and ritualistic (e.g. prayer and pilgrimage) dimensions of religious adherence. Like conscience, its scope is broader than religious adherence. However, overinclusion is less of a problem as long as we can carve out a clear subset of the value that concerns religion. We reject integrity as the foundational value of religious freedom not because it is over-inclusive, but because it is also under-inclusive-it does not include our capacious conception of a person's possible interests in religious adherence. Integrity tends to overvalue adherence that is intense, thought-through and deeply held, and may fail to adequately protect religiosity that is relaxed, flexible, or habitual. Like conscience, it also has the tendency to cast religion in a particularly Protestant image ('Here I stand, I can do no other'), and may underserve other strands of religious (non)adherence.

The value of respecting every person's decisional autonomy in matters of religious adherence is the most viable norm to underpin religious freedom. An autonomy-based rationale demands respect for a committed point of view in a way that other rationales may not. For example, a social harmony based protection for religious freedom might be content to protect only the essential practices of major religions, interference in which might cause conflict. ${ }^{34}$ The autonomy rationale, on the other hand, is acutely sensitive to the religious pluralism and diversity we see in religious practice, including sensitivity to internal diversity within religions. It extends its protection to heterodox and dissenting views and to non-religious persons. One of us has argued elsewhere in some detail why the value of preserving our decisional autonomy in matters of religious adherence is also normatively attractive for other reasons. ${ }^{35}$ The underlying premises are that personal autonomy is of immense value to individuals, that in order to be autonomous individuals must have access to a range of valuable opportunities, and that the freedom to make decisions in relation to (non)adherence to religions is one such valuable opportunity. ${ }^{36}$

\footnotetext{
${ }^{33}$ Michael Sandel, Religious Liberty - Freedom of Conscience or Freedom of Choice?, 3 UTAH L. REV. 597 (1989).

${ }^{34}$ The Indian Supreme Court tends to adopt this position.

35 JANE CALDERWOOD NORTON, FrEEDOM OF RELIGIOUS ORGANIZATIONS (2016).

${ }^{36}$ On personal autonomy generally, see Raz, supra note 8.
} 
An autonomy-based rationale has the additional advantage of protecting our capacious interest in religious adherence: it is not under-inclusive, nor unfair to non-believers. It also has significant support in case law $^{37}$ and academic literature. ${ }^{38}$ It is, of course, over-inclusive, inasmuch as decisional autonomy in matters of religious adherence is a subset of our decisional autonomy generally. Even so, decisional autonomy in matters pertaining to religious (non)adherence is a clearly identifiable subset that protects a fundamental and valuable interest.

We do not claim that religion is the only, or the most valuable, subset of decisional autonomy. Other facets of decisional autonomy (e.g. in matters of sexual relationships) also need robust protection - and as such sidestep the debate over whether religion is special except to express scepticism about the possibility. ${ }^{39}$ This scepticism is conceptual-attempts to define religion generally have failed because it is hard (if not impossible) to pin down a set of characteristics that pertain to all phenomena we agree to characterize as religions. Any effort to suggest that religion is special will necessarily need to highlight some common feature in all religions that makes religion special. The best that can be done is to imagine religion in a particular imageprivileging a certain religious tradition and identifying its core features to claim special status. But that would be an argument for why Catholicism or Buddhism is special, not why religion is special. ${ }^{40}$

Two common criticisms of the decisional autonomy rationale must be responded to. The first is that religion is often not a matter of choice for its adherents. The second it that the rationale is too individualistic. With regards to the first criticism, autonomy is too easily confused with a simplistic understanding of 'choice'. ${ }^{41}$ When we speak of 'decisional autonomy', we do not intend to suggest that everyone necessarily has a free choice in matters of religious adherence. In fact, many adherents may not feel that they have (or, indeed, that they should have) any choice in subscribing to (what they view as) the truth. ${ }^{42}$ This truth may make many imperative demands on them that leave little room for choice. ${ }^{43}$ Others may have followed the religion of

\footnotetext{
${ }^{37}$ E.g. Jehovah's Witnesses of Moscow v. Russia, 53 Eur. H.R. Rep. 4 [134]-[135] (2011); Eweida v. British Airways Plc. [2010] EWCA Civ 80 [40]; R (Begum) v. Governors of Denbigh High School [2006] UKHL 15, [2007] 1 AC 100 [93]; R (Williamson) v. Secretary of State for Education and Employment [2003] QB 1300 (CA) (2003); Syndicat Northcrest v. Amselem, [2004] 2 S.C.R. 551 (Can.). For US examples, see LAURENCE TRIBE,

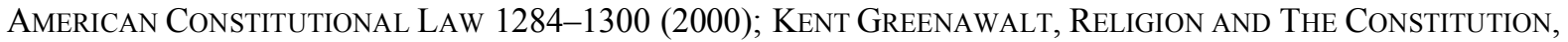
VOLUME I: FREE EXERCISE AND FAIRNESS 3-4 (2006). For a full account see Ahmed, supra note 16.

${ }^{38}$ E.g., EVANS, supra note 11; GREENAWALT, supra note 37, at 3-4. Sandel also accepts that an autonomy-based conception of religious freedom is the predominant contemporary liberal understanding of religious freedom: Michael J. Sandel, Religious Liberty - Freedom of Conscience or Freedom of Choice?, UTAH L. REV. 597, 611 (1989). See also Ahmed, supra note 16, at 239.

${ }^{39}$ We take this to be asking whether religious interests are special — and weightier - than non-religious ones.

${ }^{40}$ See generally, Koppelman, supra note 24; Andrew Koppelman, Is It Fair to Give Religion Special Treatment?, U. ILL. L. REV. 571 (2006); Christopher Eisgruber \& Lawrence Sager, Does it Matter What Religion Is?, 84 NotRE DAME L. ReV. 807 (2009); Micah Schwartzman, What if Religion Is Not Special?, 79 U. CHI. L. REV. 1351 (2012); Brian Leiter, Why Tolerate Religion? (2012); Michael McConnell, Why Protect Religious Freedom?, 123 YALE L.J. 770 (2013).

${ }^{41}$ The choice-based understanding of religious autonomy is rightly criticised. See RONAN MCCREA, RELIGION AND THE Public ORder of THE EuROPEAN Union 111 (2010). Similar criticisms apply to arguments from choice in the context of reproductive rights. See Thérèse Murphy, The Texture of Reproductive Technologies, in NEW TECHNOLOGOIES AND Human Rights (Thérèse Murphy ed., 2009).

42 See Sandel, supra note 38, at 611; John Garvey, Free Exercise and the Value of Religious Liberty, 18 ConN. L. REV. 779, 791 (1986).

${ }^{43}$ See Nicholas Aroney, Individual, Community and State: Thoughts on Jane Norton, Freedom of Religious Organizations, AustL. J. Of LEGAL PHIL. (forthcoming 2018).
} 
their parents with little thought and without ever consciously exercising any choice. Later in life, it may be psychologically very difficult for them to choose not to follow that religion. ${ }^{44}$

While we accept that an adherent may not feel they have choice in religious matters, we are employing a capacious conception of autonomy. This conception seeks to protect the agent's moral capacity to make her own decisions on matters concerning religious (non)adherence, whether or not she feels she has (or in fact has) any 'choice' in the matter and whether or not this moral capacity is ever acted upon. It protects the religious freedom of converts who actively change their religious status, of those who zealously reaffirm it, as well as those who never care to think much about it. This broad notion of decisional autonomy does not seek to relegate religious adherence to the private sphere either-it accepts that religious performance can and does have a public dimension. Nor does it reject communal dimensions of religious adherence - if communal performance matters to the adherent, it forms part of her decisional autonomy in religious matters.

Furthermore, the term 'autonomy' is used here to mean an aspirational value that ought to be sought and realized, rather than implying any descriptive claim about our actually possessing autonomy. ${ }^{45}$ Of course some of us, in the descriptive sense, have more autonomy than others, and many don't have adequate autonomy. In the case of religion, it is no coincidence that most people adhere to the religions of their parents. Even so, there are good reasons for the state to take an adherent's self-proclaimed religious affiliation at face value in the absence of any proof of direct coercion, even if such adherence is deluded, irrational, unfairly influenced, and so on. ${ }^{46}$ The autonomy loss resulting from the non-recognition or mis-recognition of one's selfproclaimed religion is unlikely to be offset by any autonomy gains accruing from efforts by the state to help them 'see light'. The state telling me my religion might have got it wrong is usually better than it telling me I have got my religion wrong. An autonomy-based rationale dictates that we take the committed point of view of the adherent seriously. Individual decisional autonomy in religious matters would be left with little content if any external body or person could determine whether an individual has freely chosen to adhere to a religion, what that religion is, what adherence to that religion entails, or who (if anyone) is an authority on what an adherence to that religion requires.

While the autonomy rationale takes the committed perspective of the adherent seriously, the rationale itself need not be endorsed as adequate justification for religious freedom from the committed point of view. It is not even clear, from the internal point of view of every religion, that the protection of (everyone's) religious freedom is valuable. It is only the content of the claim that the adherent seeks protection for that is discerned from the committed point of view; the reasons for protecting such claims (whether autonomy, toleration, or something else) need not be endorsed by the adherent's committed viewpoint. Nor is our argument that the law itself should adopt a committed viewpoint in matters of religion. We agree with the Rawlsian position that the state's reasons must always and only track public reasons, ${ }^{47}$ even as public reasons sometimes require the state to tolerate, respect or protect actions grounded in sectarian reasons. Our argument here is simply that there may be good (public) reasons for the state to protect an adherent's committed internal perspective in matters of religion.

\footnotetext{
${ }^{44}$ See Leslie Green, Rights of Exit, 4 Legal THEORY 165 (1998); Susan Moller Okin, "Mistresses of Their Own Destiny": Group Rights, Gender, and Realistic Rights of Exit, 112 ETHICS 205, 216-222 (2002).

${ }^{45}$ See generally Raz, supra note 8.

${ }^{46}$ R (Begum) v. Governors of Denbigh High School [2006] UKHL 15, [2007] 1 AC 100 [95]-[96].

${ }^{47}$ See John Rawls, Political Liberalism (1996).
} 
The second objection to the decisional autonomy rationale might be that it is too individualistic. We acknowledged, however, the importance of communal dimensions of religious practice in certain religions in the preceding section. While the rationale values autonomy of individuals, it is compatible with - and even requires - the protection of any communal dimension of religious adherence. ${ }^{48}$ This will be the case so long as the collective or communal dimension is (intersubjectively as well as from the committed perspective) part of the religion. In other words, if communal worship is important to the individual's adherence to her religion, an autonomy-based rationale will protect it. Participation in the life of a religious community, or the acceptance of the religious authority of one's church, can therefore be aspects of religious adherence ${ }^{49}$ Furthermore, the essence of religious practice itself often depends on social forms - i.e. forms of behavior which are widely practiced within that group. ${ }^{50}$ While it is individual believers who constitute a religious community, the group itself may have 'a strong role to play in constructing individual religious affiliation' ${ }^{51}$ None of this needs to be denied by anyone who subscribes to the autonomy rationale for religious freedom. Any adherent who disagrees with such collectivity requirements is simply a dissenter within that group (whose right to dissent is equally protected) ${ }^{52}$ In other words, there surely are collective dimensions to freedom of religion, but these are derivative of the individual's right to that freedom. ${ }^{53}$

\subsection{The Right against Religious Discrimination}

Unlike the right to freedom of religion, the right against religious discrimination is not a standalone guarantee. It is a species of the more general freedom from discrimination based on certain protected characteristics which, apart from religion, tend to be race, gender, disability, sexual orientation, language, ethnicity and so on. As such, unless we have very good reasons to think otherwise, the rationale for prohibiting religious discrimination must be found in the rationale for prohibiting discrimination more generally. ${ }^{54}$

The main function of the prohibition of discrimination, as one of us has argued before, is to prevent, reduce or eliminate any substantial, abiding and pervasive advantage gaps between certain cognate groups (i.e. groups defined by the same personal characteristic, such as men and women, or Christians and Sikhs). ${ }^{55}$ These advantage gaps could be political, material, or socio-cultural, but usually tend to manifest in all these dimensions simultaneously and reinforce each other. The underpinning normative argument is that we should care about such advantage gaps between groups because they reduce the ability of members of the (relatively) disadvantaged groups to access certain basic goods - negative freedom, an adequate range of valuable opportunities, and self-respect - whose secure enjoyment is essential to our ability to live a free and flourishing life. ${ }^{56}$ Thus, even though the object of discrimination law's

\footnotetext{
48 See CAlderwoOd NorTON, supra note 35.

${ }^{49}$ Hasan \& Chaush v. Bulgaria, 34 Eur. H.R. Rep. 55 [62] (2002).

${ }^{50}$ See RAZ, supra note 8, at 308.

${ }^{51}$ See CALDERWOOD NORTON, supra note 35, at 24.

52 See Green, supra note 44.

${ }^{53}$ See Calderwood Norton, supra note 35. Cf. Julian Rivers, Religious Liberty as a Collective Right, in LAW AND RELIGION (Richard O’Dair \& Andrew Lewis eds., 2001).

${ }^{54}$ See generally Dworkin on local priority within 'departments' of law: RONALD DwORKIN, LAW's EMPIRE 250f (1986).

${ }^{55}$ See KHAITAN, supra note 25. For comparable accounts see Owen Fiss, Groups and the Equal Protection Clause, 5 Philosophy and Public Affairs (1976); Cass Sunstein, The Anticaste Principle, 92 Mich. L. ReV. 2410 (1994).

${ }^{56}$ On how this happens, see KHAITAN, supra note 25, at ch. 5.
} 
immediate attention is groups, in keeping with the contemporary human rights tradition, the ultimate commitment is to the freedom and well-being of (all) individuals..$^{57}$

One need not accept the details of this rationale for discrimination law. But almost all credible accounts of this area of law - at least accounts that take the Anglo-American law concerning the regulation of discrimination seriously - accept that the current or historical disadvantage faced by social groups lies at the heart of discrimination law. This is true of egalitarian accounts, ${ }^{58}$ freedom-based accounts ${ }^{59}$ as well as expressive accounts ${ }^{60}$ that seek to explain discrimination law. Given this consensus - at least at a broad level — it would be very surprising if the main purpose of the law regulating religious discrimination was to protect individual religious (non)adherence (rather than to secure an unsaddled membership of one's religious group). This theoretical consensus over the group focus in discrimination law may seem surprising to some practitioners, especially if they notice that typically, the claimants in discrimination law are individuals, and that the protection is offered symmetrically to both the advantaged and the disadvantaged groups. To answer this objection, we need to distinguish this systemic-functional claim about the overall purpose of discrimination law from specific design issues. Drawing upon Rawls and Hart, one of us has argued elsewhere that full transparency between the functional goal of discrimination law and the design of particular rules that regulate discrimination may actually be counterproductive. ${ }^{61}$ To put the point differently, the goal of reducing relative group disadvantage may be ill-served if courts start asking in each case what outcome will best reduce such disadvantage. Additional considerations of fairness, pragmatism, clarity, certainty, and a normative commitment to liberalism also inform the design of antidiscrimination rules. Considerations such as these, for example, dictate that (in general) discrimination law should protect not only the relatively disadvantaged group but also its cognate advantaged groups. ${ }^{62}$

On the reading we have outlined, non-committal religious group membership, rather than committed religious adherence, lies at the heart of discrimination law. ${ }^{63}$ Because religion is one of the characteristics that creates substantial, abiding, and pervasive advantage gaps between cognate groups, it is a protected characteristic in discrimination law, alongside race, sex, sexual orientation, disability, pregnancy, ethnicity, and other characteristics. It follows that the big-picture concern of discrimination law is to prevent or mitigate a caste-like organization of society on religious lines where certain religious groups end up with a lower class status. Burdening adherence to a particular religion may well increase the (political, material, social) advantage gap between religious groups, but there are other ways this can happen too. It may be, for example, that most members of a minority religion are poor, or that they are recent immigrants, or that they are subject to widespread hostility and ostracism by the majority religious group because of their racial difference, and therefore suffer relative group disadvantage. Discrimination law is indifferent to the cause of such disadvantage. Rather, it is the fact or likelihood of relative group disadvantage that this area of law seeks to counter.

\footnotetext{
${ }^{57}$ See KHAITAN, supra note 25 , at $38 \mathrm{f}$ (on the 'eccentric distribution condition' for more clarification on the group orientation of discrimination law).

${ }^{58}$ See, e.g., SANDra Fredman, Discrimination Law (2002); Catharine MacKinnon, Toward a Renewed Equal Rights Amendment: Now More than Ever, 37 HARV. J. OF L. \& GENDER 569 (2014).

59 See, e.g., Sophia Moreau, What is Discrimination?, 38 Phil. \& PuB. AfF. (2010); KhaitAn, supra note 25.

${ }^{60} \mathrm{See}$, e.g., DebOrah Hellman, When is Discrimination Wrong? (2008).

${ }^{61}$ See KHAitAn, supra note 25.

62 See id. at ch. 6.

${ }^{63}$ Just as the protected characteristic 'sex' is akin to the personal characteristic of sex and gender rather than sexual intercourse. Of course, group membership and behavior are related, but not reducible to each other.
} 
As we move from the systemic concern that discrimination law has with group disadvantage to specific design issues, we notice - at least outside the context of religious discriminationa rather tightly regulated scope of what counts as discrimination. In the limited contexts that discrimination law regulates, a claimant must establish a prima facie case of direct or indirect discrimination against her. The determination is objective, and requires the claimant to show either that she suffered some non-remote adverse effect:

(a) because of the defendant's intentional reliance on a protected characteristic, ${ }^{64}$ or

(b) that the defendant's facially neutral policy had such adverse effect

i. either exclusively on members of her group, ${ }^{65}$ or

ii. on those who disproportionately belong to her group. ${ }^{66}$

British law treats (a) and (b)(i) as instances of direct discrimination, and (b)(ii) as a case of indirect discrimination. Cases in (a) that involve the intentional targeting of a religious group, or even the intentional use of religion in a decision, tend to be rare, and when they come up, tend to be easier to decide. It is the set of cases in (b) that are the most controversial and shall be our focus in the discussion that follows. These cases involve the impact of a facially neutral policy on the claimant's group. In such group impact cases, discrimination must be established by showing comparative adverse effect on the claimant's group, in relation to a cognate group. So, in the case of religion, a claimant must show that the policy in question not only affected her but also that it (exclusively or disproportionately) affected other members of her religious group when compared with some other cognate group. For example, a Muslim claimant will need to show that an employer who requires a university degree for a manual job in an area where Muslims are disproportionately less likely to have university degrees affected not just her (as a potential applicant who did not meet the criterion) but also disproportionately affected Muslims (in that area) generally.

Whether a protected group suffered adverse impact is determined objectively, rather than subjectively. This objective standard sets a relatively high bar for making a prima facie case of discrimination. This high bar is unavoidable, to some extent, given that discrimination law's primary concern is with group disadvantage. While the entry threshold is relatively high, however, the possibility of justifying a successful prima facie case is relatively slim. Direct discrimination admits to very few and very high threshold exceptions. Moreover, even though indirect discrimination can be justified, certain types of justifications - such as the business profitability, consumer preference or competitive disadvantage-are typically barred. Although the claimant has a demanding threshold to cross in order to make a prima facie case of discrimination, once she has met this threshold the possibility that the discrimination she faces might be justified is slim and usually assessed strictly by courts.

Religious group membership (chosen or otherwise) saddles us with privileges and disabilities. Given this, something would be lost (and very little gained) if the right against religious discrimination was reduced to just another means of protecting our interest in religious adherence. While there may be good strategic reasons for practicing lawyers to try to achieve these outcomes, the erasure of the distinction we are hoping to highlight will not only create

\footnotetext{
${ }^{64}$ British/European law treats this as direct discrimination: Bougnaoui v. Micropole SA (2017) Case C-188/15 (E.C.J.). Even these cases that track intentional use of a protected characteristic as a basis of classification are ultimately concerned with the adverse effect of such use on the protected group. See KHAITAN, supra note 25, at ch. 6.

${ }^{65}$ This is also direct discrimination in British/European law. See James v. Eastleigh B.C. [1990] 2 AC 751; Bull v. Hall [2013] UKSC 73.

${ }^{66}$ This alone is indirect discrimination in British/European law. See Essop v. Home Office (UK Border Agency) [2017] UKSC 27.
} 
conceptual confusion but will ultimately be a bad thing for the protection of our religious interests.

We should emphasise that the sharp distinction we are drawing between the two rationales for human rights protection of religious interests - religion as adherence and religion as group membership - is a conceptual one. The two religious interests can, after all, overlap. It is evidently true that often protection of religious freedom is likely to reduce not just the religious, but also social, material, and political disadvantages faced by its adherents. And sometimes discrimination against members of a group will also impinge upon religious adherence. In fact, if we map all cases of breaches of the right to religious freedom and all cases of breaches of the right against religious discrimination, the overlap might indeed be significant. This does nothing, however, to minimise the existence or significance of the conceptual and normative distinctions we are trying to draw out. Our argument is that it is not the purpose of discrimination law to secure religious freedom and nor is it the purpose of the right to religious freedom to reduce religious group disadvantage. In the next section we will also see important implications of the distinction with respect to the scope of the two rights. In particular, the scope of the two rights, the possibility of justifying their infringements and the relationality between rights-holders and duty-bearers are significantly different. In the final section, we will see that the areas where the two rights do not overlap are not insignificant.

\section{Implications of the Distinction}

The distinctions we have drawn between the two different religious interests (adherence and group membership) and their corresponding protector rights (freedom of religion and the right against religious discrimination) have important implications for legal doctrine. In this section, we will outline four of these distinctions in more or less detail.

\subsection{Scope of the Rights}

The first implication of the distinction we have drawn between the two rights relates to the scope of the rights. What is the scope of the right to freedom of religion, justified on the basis of the need to respect decisional autonomy in matters of religion? The short answer, which follows from our capacious notion of religious adherence, is that it is very wide. The long answer recalls the three success conditions for any understanding of religion: that it should not be over-inclusive by treating my preference between (say) apples and oranges as a religious issue; that it should not be under-inclusive by privileging orthodox or majoritarian views within a religion or by privileging belief-based religions over practice-based ones; and that it should not be unfair to non-believers. We also note that the need for respecting decisional autonomy is weighty only because questions of religion (for many adherents, but also for many nonadherents) are weighty.

Translating these findings into a neat legal test is not going to be easy. It is our claim, however, that any test that accepts our rationale for protecting religious freedom is unlikely to demand more than the plausibility of the religious character of the object of the claim and the sincerity of the claimant's adherence. At least conceptually, the plausibility inquiry is an intersubjective one, and the sincerity inquiry explores the committed dimension of religious (non)adherence.

The plausibility test can be stated thus:

"for a given demand by $\mathrm{X}$ to be permitted to $\varphi$ (or not $\varphi$ ), might a reasonable person sufficiently familiar with the $X$ 's socio-cultural context recognize that $\varphi$-ing has a religious character."

If such a person would recognize $\varphi$-ing as having a religious character, the plausibility threshold is met. This limb of the inquiry performs a gatekeeping function. It ensures that there 
are some limits to the scope of religious freedom. It recognizes that religiosity is an intersubjective cultural phenomenon, i.e. it exists as a phenomenon shared between multiple conscious minds, and cannot be invented by a lone individual entirely out of thin air. To be clear, the test does not require the reasonable observer determine which, if any, specific religion demands or forbids $\varphi$-ing. The plausibility claim only tests the character of the claim intersubjectively, leaving its content to be determined entirely by the subjective, committed, sincere viewpoint of the adherent.

The plausibility test also ensures fairness to non-believers by respecting their claim to refuse to $\varphi$. It should be obvious that what matters is not the religious character of the claim itself, but the religious character of the object of the claim $(\varphi)$. For example, let us say that $\varphi$ stood for 'Marrying a person of the same sex is immoral'. For a person making this claim, it is likely (although not necessary) that the object of the claim has a religious character (say, her religious beliefs tell her that same sex marriages are immoral). If so, however, a claim by a citizen that 'Marrying a person of the same sex is not immoral' also has a religious object, ${ }^{67}$ insofar as it rests on the rejection of at least an aspect of her opponent's religion. This formulation avoids the suggestion that atheists are also somehow 'religious'. Consider another, arguably more paradigmatic, claim that has a religious object: 'God exists'. Its negation-'God does not exist' - also has a religious object simply because it is the negation of a religious object. This does not make the person making this claim the adherent of any religion, and their reasons for making it may have nothing to do with adherence to any religion. ${ }^{68}$

A different way to put the point might be to use the claimants' points of views. If the person making the claim views themselves as making a religious claim, the object of the claim itself acquires a religious character such that its negation will also retain such character. This is religious freedom, which after all, entails freedom of religion as well as (x's) freedom from (y's) religion. ${ }^{6}$ Our symmetry-seeking formula alone avoids the pitfalls of interpreting freedom from religion too narrowly or too broadly. Current legal practice affords too little protection to atheists by confining their interest in freedom of religion to not being coerced to follow or adopt any religion. While freedom from forced conversion is important, they cannot make any claims concerning other beliefs and practices that adherents of a religion can make. On the other hand, if we accord all beliefs and practices of atheists the same level of protection that religious beliefs and practices have, atheists will be protected to a far greater extent than religious adherents (for possibly everything they do might be seen as flowing from their 'atheism'). Our symmetric formula, on the other hand, irrevocably ties the scope of the protection for the non-religious to that of the religious - they sink and swim together. This symmetry, and the fairness inherent in it, is a key reason why it should be accepted. This insight has important implications that will be discussed in Section 5.2.

The sincerity inquiry, on the other hand, ensures that the test is not too narrow. It asks: does the claimant sincerely hold that $\varphi$-ing (or not $\varphi$-ing) follows from their religious commitments (including, obviously, a commitment to rejection of religion). This test determines the content of the claim, and is not subject to any reasonableness or community-standard inquiry. Usual rules of evidence law should normally suffice for the purposes of the sincerity inquiry. In order to avoid an onerous and unnecessary evidentiary burden being placed on a religious claimant to prove their subjective state of mind, it is better for the court to presume sincerity unless there

\footnotetext{
${ }^{67}$ Obviously, the primary reason for wanting to marry a person is likely to be different—probably romantic love or companionship. It does not matter that the religious dimension of the object of the claim is secondary, or even peripheral.

${ }^{68} \mathrm{Cf}$. DwORKIN, supra note 14.

${ }^{69}$ See James Nickel, Why Basic Liberties Are Bilateral, 17 L. \& PHIL. 627 (1998).
} 
are reasons to displace the presumption. There is no objective merit-based test that $\varphi$-ing needs to satisfy in order to fall within the scope of the right. Autonomy demands that this be a subjective inquiry, with the inevitable implication that religious freedom potentially has a very wide and unpredictable scope.

This wide scope is in part because religious adherence makes practical demands on believers not only with regard to worship, ritual, and other forms of religious performance but potentially in every aspect of their lives. The internal point of view of religious adherents may not even recognize the religious-secular distinction. ${ }^{70}$ Religious freedom therefore casts its net very wide. What makes the scope of the freedom even broader is the question of complicity: a believer's religion may prohibit her not only from $\varphi$-ing, but also from becoming in any way complicit in the commission of $\varphi$ (by others). For this reason, a belief that forbids the killing of animals may also require not eating meat, even if the animal was killed by another. Of course, whether such complicity is in fact prohibited by the belief in question will be subject to the sincerity and plausibility tests, but that is all. ${ }^{71}$ An adherent might believe, for example, that providing employee health insurance which has provisions for abortion or contraception could make him complicit in abortion or birth control, which his religion prohibits. One might claim that even hiring (and paying a salary to) an employee who might use her salary to get an abortion implicates his religious freedom. The point isn't intended to be facetious. ${ }^{72} \mathrm{~A}$ potentially extremely wide and unpredictable scope for religious freedom is the inevitable consequence of adopting a largely subjective approach. But respecting decisional autonomy in matters of religion permits no other approach. Of course, this does not mean that the law will necessarily protect all these beliefs and their manifestations - that has to be determined at the justification stage. It is, however, more honest of law, and more respectful of a person's decisional autonomy with regard to her religious (non)adherence, to be told that other considerations necessitate a restriction on her religious freedom, than to be told that what she claims is part of her religion is in fact not.

Together, the tests of plausibility and sincerity satisfy all our success conditions. The plausibility test determines whether the claim in question is within the remit of our adopted rationale - decisional autonomy in matters of religion. The sincerity test allows a very wide space for autonomous decision-making within that space. A more demanding test would entail someone else (usually the state) telling an adherent what her religion in fact demands, and would therefore be incompatible with her decisional autonomy in relation to religion. ${ }^{73}$ Such objective tests would especially hurt heterodox and dissenting voices within religions, voices

\footnotetext{
70 Alvin Esau, "Islands of Exclusivity": Religious Organization and Employment Discrimination, 33 U. BRIT. Colum. L. ReV. 719, 732 (2000); ReX AdHar \& IAN Leigh, Religious Freedom In the Liberal State 125 (2013) (criticizing the distinction in relation to belief and practice); Joel Harrison, Autonomy and the Liberal Imagination in Jane Calderwood Norton's Freedom of Religious Organizations, AustL. J. OF LEGAL PHIL. (forthcoming), available at https://papers.ssrn.com/sol3/papers.cfm?abstract id=3014490.

${ }^{71}$ Cf. Douglas NeJaime and Reva Siegel, Religious Accommodation, and its Limits, in a Pluralist Society, in Religious Freedom And LGBT Rights: Possibilities AND Challenges For Finding Common Ground (Robin Fretwell and William Eskridge, Jr. eds., 2018 forthcoming).

${ }^{72}$ See First Amendment Defense Bill, H.R. 2802, 114th Cong., (2015).

${ }^{73}$ Our claims are at sharp contrast with the practice in jurisdictions like India which only protect 'essential practices' of a religion, judged by experts in those religions. In the United Kingdom, a practice will be a manifestation of religious belief only if it is 'intimately linked' to that belief as judged by the court: see $\mathrm{R}$ (Playfoot) v. Governing Body of Millais School [2007] EWHC 1698 (Admin) at [21] (wearing of purity ring not protected by right to religious freedom because not intimately linked to religious belief in premarital chastity); $\mathrm{R}$ (Williamson) v. Secretary of State for Education and Employment [2005] UKHL 15, [2005] 2 AC 246 at [32],[63]. By contrast, courts in the United States have refused to inquire into the 'centrality' of a particular activity to a religion: Employment Division v. Smith, 494 U.S. 872, 886-887 (1990) (Scalia J.).
} 
that most need to secure their religious freedom, and also hinder the evolution and dynamism of religions by ossifying dominant orthodox traditions.

Before we move on, a word on whether pacifism and environmentalism can have a religious character and therefore be protected by the right to religious freedom. Pacificism and environmentalism may be aspects of certain religions (many Quakers, for example, believe that their religious adherence requires pacifism), but are otherwise unlikely to satisfy the plausibility test as such. Unlike atheistic claims whose objects have a religious character (even though the claim itself does not have a religious character), the objects of pacifist and environmental claims - qua their pacifism or environmentalism — do not have a religious character. This does not mean that they should not be protected. In bills of rights, religious freedom is usually articulated as 'freedom of religion and belief', and there may well be good normative and policy reasons to protect beliefs such as pacifism and environmentalism under such rights. This paper is not concerned, however, with what should populate the 'and belief' part of the right and expresses no opinion on that matter. All we wish to do is clarify the category distinction between claims based on Judaism, Taoism and atheism on the one hand, and those based on pacifism and environmentalism as such.

In contrast with the right to freedom of religion, the scope of the right to be free from religious discrimination, on our account, is far narrower. Under British/European law, there are two ways of showing that an act is directly discriminatory: either by showing that the act makes intentional use of a protected characteristic (such as religion) ${ }^{74}$ or by showing that there is an exact coincidence between the beneficiaries and victims of a facially neutral act on the one hand and members of a protected group and its cognates on the other (e.g. an act that burdens all the Muslims it applies to, and no one who benefits is a Muslim). ${ }^{75}$ Given the diversity of religious adherence within a religious group, it is highly unlikely that a facially neutral act will achieve such exact coincidence in the context of religious discrimination. For example, a ban on all head-coverings will affect many Muslim women and many Sikh men, but it will not affect all Muslim women or all Sikh men that it applies to (since, not all Muslim women wear headscarves, nor do all Sikh men wear turbans). Such a ban is therefore more likely to amount to indirect discrimination, which demands instead that the protected group be affected disproportionately. ${ }^{76}$ In most cases of religious discrimination, an intentional use of religion as a classificatory basis (for example a ban on Islamic headscarves, or even a ban on all headcoverings motivated by the desire to target Islamic headscarves) alone is likely to qualify as direct discrimination. ${ }^{77}$ Most other cases where members of a religious group are disproportionately burdened by a facially neutral policy will amount to indirect discrimination.

Implicit in the preceding paragraph is a key claim that needs to be brought out more clearly. The claim is that the relevant religious group should be identified sociologically from the noncommittal perspective. This claim is important because the level at which a 'group' is identified for protection in discrimination law is not necessarily clear cut. While it is true that a general ban in head-coverings will not affect all Sikh men, it will affect all Sikh men who wear turbans as a religious requirement. On this interpretation, every act that burdens religious freedom will necessarily also amount to an act of discrimination (although the reverse will still not be true). It is the premise of this article, however, that the two rights are best understood to be performing

\footnotetext{
${ }^{74}$ CHEZ Razpredelenie Bulgaria AD v. Komisia za Zashtita ot Diskriminatsia (2015) Case C-83/14 (E.C.J.), [2015] I.R.L.R. 746 at [75], [76], [95].

${ }^{75}$ Bull v. Hall [2013] UKSC 73, [2013] 1 W.L.R. 3741 at [19].

${ }^{76}$ Griggs v. Duke Power Co., 401 U.S. 424 (1971); Essop v. Home Office (UK Border Agency) [2017] UKSC 27.

${ }^{77}$ See Bougnaoui v. Micropole SA (2017) Case C-188/15 (E.C.J.).
} 
distinct functions in human rights adjudication. The difficulty with identifying the relevant religious group with reference to adherence is that it blurs the boundaries between the two rights: it fails to take the distinction between a person's committed interest in religious (non)adherence and her non-committal interest in her religious group membership sufficiently seriously. It also fails to adequately take notice of the different normative foundations for the two rights. Furthermore, an adherence-based, rather than a sociological understanding of a religious group, will leave those perceived to be members of the group - even if they do not adhere to its religion - without the protection of discrimination law. After all, an atheist whose job application is rejected on the basis that she has a Jewish-sounding name is as much a victim of religious discrimination as one who is in fact committed to Judaism. For all these reasons, it is essential for the purposes of discrimination law that the relevant religious group should be identified sociologically from the non-committal perspective, rather than with reference to individual religious adherence. ${ }^{78}$ The implication of this claim is that the threshold required to be satisfied in order to make an antidiscrimination claim is relatively high.

\subsection{Relationality}

The second implication of the distinction we have drawn between the two rights concerns relationality. Human rights are typically considered to be claims against ('vertical') infringements by the state. It is accepted that the state may not, without adequate justification, infringe upon one's freedom of religion or discriminate against her on the ground of religion. The controversial question is whether, and to what extent, these rights should be treated as claims in private ('horizontal') relationships. This subsection explores this issue. To be clear, we do not take the public person/private person distinction to be a rigid one. We accept that between the spectrum-defining end points of the state and a natural individual lies a whole range of bodies with different degrees of publicness. ${ }^{79}$

We also note that the horizontality-verticality distinction does not completely capture various dimensions of relationality pertaining to the operation of a right. Even if a right does not have horizontal application, this does not mean that it has no role to play in defining private relationships. In order to appreciate what we are going to say in regard to relationality fully, it is helpful to first revisit Hohfeld's famous analysis of rights in terms of how they structure relationships between persons. Hohfeld showed that legal rights were not some 'things' out there, but a type of relationship between persons. Furthermore, the language of 'rights' was ambiguous, and could refer to any of four different types of relationships: liberty, ${ }^{80}$ claim, ${ }^{81}$ power and immunity. A brief, jargon-laden, snapshot of Hohfeld's categories can be glanced over in the table below:

\begin{tabular}{|l|l|l|}
\hline & Jural Opposites: & Jural Correlatives: \\
\hline $\begin{array}{l}\text { Primary } \\
\text { Concepts }\end{array}$ & $\begin{array}{l}\text { If A has a claim, then A lacks a no- } \\
\text { claim. }\end{array}$ & If A has a claim, then B has a duty. \\
\hline
\end{tabular}

78 The UK Court of Appeal conducts a similar analysis to determine whether a no-neck-jewelry policy disproportionately impacts cross-wearing Christians: Eweida v. British Airways Plc. [2010] EWCA Civ 80 [18][19]. Although the Eur. Ct. H.R. disagreed with the outcome of the judgment, it did so on religious freedom grounds rather than on religious discrimination basis.

${ }^{79}$ See Khaitan, supra note 25 , at ch. 7.

${ }^{80}$ Hohfeld called this 'privilege', but liberty is generally accepted as a better term in the Hohfeldian literature.

${ }^{81}$ Again, Hohfeld referred to this concept as a 'right', but that could lead to confusion between the sub-category and the broader category he was disambiguating. The literature now mostly sticks to 'claim' as a better descriptor of what he intended. 


\begin{tabular}{|l|l|l|}
\hline & $\begin{array}{l}\text { If A has a liberty, then A lacks a } \\
\text { duty. }\end{array}$ & $\begin{array}{l}\text { If A has a liberty, then B has a no- } \\
\text { claim. }\end{array}$ \\
\hline $\begin{array}{l}\text { Secondary } \\
\text { Concepts }\end{array}$ & $\begin{array}{l}\text { If A has a power, then A lacks a } \\
\text { disability. }\end{array}$ & $\begin{array}{l}\text { If A has a power, then B has a } \\
\text { liability. }\end{array}$ \\
\cline { 2 - 3 } & $\begin{array}{l}\text { If A has an immunity, then A lacks a } \\
\text { liability. }\end{array}$ & $\begin{array}{l}\text { If A has an immunity, then B has a } \\
\text { disability. }\end{array}$ \\
\hline
\end{tabular}

It is unnecessary to explain these well-known categories in detail. The most important distinction, for our purposes, is the one between a liberty and a claim. My liberty to $\varphi$ is not the same thing as my claim that you let me $\varphi$ or facilitate my $\varphi$-ing. When I have a liberty to $\varphi$, it simply means that you do not have a claim against me to not $\varphi$. On the other hand, when you have a claim against me to not $\varphi$, I have a duty (to you) to not $\varphi$, and am therefore not at liberty to $\varphi$.

Some examples should clarify the complex Hohfeldian definitions of these concepts. In a jurisdiction that has a finders-keepers law, I am at liberty to pick up an unclaimed ten dollar note lying on a public footpath. Suppose that you and I see the note at the same time, but you are quicker than I am and pick it up before me. Although I had a liberty to pick it up before you did, after you have done so, I am no longer in a position to exercise that liberty. Moreover, I have no claim against you. The situation is likely to be different if the note was found on my property. In this case, the law is likely to recognize my claim over the note found on my property against you. You would likely have a duty to give me the note. Take another example: I am at liberty to speak, but I do not - normally - have any claim against you to listen to what I have to say. In certain circumstances, however, I may well have a claim to be heard, for example by a court which is trying me for an offence. A final example: in most liberal jurisdictions, I am at liberty to have consensual sex with any other adult person. But I have no claim against any other person to have sex with me (although some jurisdictions still recognize the concept of 'conjugal rights', which grants a person a claim to have sex with their spouse). It should be clear by now that a horizontally applicable 'right' gives me a Hohfeldian claim against you. But even if the 'right' is only a mere liberty (between private persons), and therefore lacks a horizontal dimension, it does not mean that its operation is irrelevant to how private relationships are structured. If I have the liberty to $\varphi$, another private person may frustrate its exercise in certain permitted ways (e.g. by picking up the dollar bill before me). But they may not prevent me from exercising it, or visit any penalty on me for my having exercised it (whether directly or by using the law's coercive power). These examples bring out another feature of the distinction: whether a legal system treats a right as a liberty or a claim is a normative choice that it makes. It is not a matter that conceptual analysis can settle. ${ }^{82}$ The issue before us is how the two rights (both of which are claims against the state) should structure relations between private persons. We will show that the law's treatment of the right against religious discrimination as a (limited) claim between private persons is justified, but that the right to religious freedom should remain a liberty in private contexts.

Our claim is that a right to religious freedom should remain a liberty in private contexts. Recall our plausibility test for determining whether a person is claiming an interest in religious (non)adherence:

\footnotetext{
82 See Stephen Hudson \& Douglas Husak, Legal Rights: How Useful Is Hohfeldian Analysis?, 37 PHIL. STUD.: AN INT'L J. FOR PhIL. IN THE ANALYTIC TRADITION 45 (1998).
} 
"for a given demand by $\mathrm{X}$ to be permitted to $\varphi$ (or not $\varphi$ ), might a reasonable person sufficiently familiar with the $X$ 's socio-cultural context recognize that $\varphi$-ing has a religious character."

Under our approach (designed to respect the decisional autonomy of the religious adherent and the non-adherent), if $\varphi$-ing has a religious character, not $\varphi$-ing must have it too. Thus, every claim by $\mathrm{X}$ to be permitted to $\varphi$ against $\mathrm{Y}$ could be met with an opposite claim by $\mathrm{Y}$ to not be subject to $\varphi$-ing by $\mathrm{X}$. So, a claim by a Hindu man that the eating of beef by non-Hindus breaches his religious freedom will always face a potential reply from a non-Hindu beef eater who does not wish to be subject to Hindu religious norms. The problem can be avoided only if $\mathrm{Y}$ herself does not possess the right to religious freedom-which is true for the state, but not true for private individuals.

It could be argued that religious freedom could still be treated as a claim, rather than a liberty. This is because the same claim made on either side of a dispute would lead to their mutual cancellation only if the two claims are of equal weight. A judicial balancing of the opposite claims could, in theory, evaluate their respective weight, intensity or centrality. These inquiries, however, would require judicial interrogation of the internal and subjective dimensions of religious (non)adherence - something that, on our approach, would be inimical to religious freedom and should be avoided as far as possible. It is better therefore if religious freedom is treated, in the context of private relationships, as a liberty rather than a claim. In fact, this normative insight might hold for most rights that track our interest in the freedom to pursue the good (as opposed to rights that directly track our interest in the good). ${ }^{83}$

The right against religious discrimination does not suffer a similar difficulty concerning simultaneous claims. First, while it is theoretically possible for both parties to a dispute to have a simultaneous claim of religious discrimination against each other arising out of the same set of facts, these cases are likely to be rare. ${ }^{84}$ Whatever little possibility there might have been for such cases to exist is obviated by the fact that in most common law jurisdictions, the duty to not discriminate applies only in specified spheres of quasi-public activities (such as employment, housing and retail) and flows uni-directionally (i.e. from the landlord to the tenant, but not the other way around). The limited horizontality of discrimination law is justified not because of claims that cancel each other out, but for other reasons that need not concern us here. ${ }^{85}$ Even if, somehow, one ends up with a case with mutually antagonistic antidiscrimination claims on both sides, since these claims are founded upon public, noncommittal viewpoints, there is no reason for the state to refrain from adjudicating upon their respective merit, cogency, weight and so on. For this reason, horizontal application of discrimination law does not pose institutional challenges comparable to those posed by that of religious freedom.

Religious freedom should remain a liberty, at least in cases where both parties possess the right to religious freedom. Whether it can be a claim against quasi-public bodies (like corporations) that lie in between the state and natural individuals, would depend on whether these non-natural

\footnotetext{
${ }^{83}$ See Section 3 above.

${ }^{84}$ It is also difficult to think of examples of cases where both parties have simultaneous claims of discrimination against each other on different grounds. Even in Bull v. Hall, where Christian Bed and Breakfast owners who refused to give a double bedroom to a gay couple complained of religious discrimination, they did so against the state, and not against the gay couple. See Bull v. Hall [2013] UKSC 73.

${ }^{85}$ For details on these reasons see KHAITAN, supra note 25, at ch. 7.
} 
persons possess the right to religious freedom. ${ }^{86}$ We will leave this thorny question to another day.

\subsection{Non-Zero-Sum Benefits, Expressive Harms, and Religious Establishment}

The third key distinction between freedom of religion and the right against religious discrimination is with regard to their attitude to non-zero-sum benefits. Non-zero-sum benefits to any one religion/religious group do not violate religious freedom, but they do discriminate. Non-zero-sum benefits are benefits that are given to the adherence of any one religion, that do not burden adherence to other religions. Examples of such benefits include a provision for a special subsidy to Muslims who wish to undertake the Haj pilgrimage, for a Christian chapel at the workplace, or for the establishment of Buddhism as the state religion. These benefits are non-zero-sum, at least in the material sense, because while they benefit the adherence of one religion, they do not - on their own-burden adherence to any other or to no religion at all. Provision for a Haj subsidy does nothing to constrain a devout Hindu's ability to adhere to her religion. These non-zero-sum benefits, we argue, do not infringe the religious freedom of nonadherents of the religion being benefited. There may well be (and, we will shortly argue, there indeed are) good reasons why the state should avoid selectively benefiting adherence to certain religions, but the protection of religious freedom is not one of them. This argument follows from our underlying rationale for religious freedom - there is nothing in non-zero-sum benefits for adherence to a religion that, on its own, affects a person's decisional autonomy with respect to her own (non)adherence.

Two objections might be raised against our claim that non-zero-sum benefits do not affect the religious freedom of non-adherents. First, it might be argued, that benefits for the chosen religion, even if non-zero-sum, would incentivise adherence to it (at least by those motivated more by worldly benefits than by ultimate salvation). While this may be true, recall that our decisional autonomy-based account is highly subjective and protects religious adherence of the intense and the frivolous, and does not interrogate one's motives for adherence (so long as the adherence itself is sincere and not a sham). If so, there is no cost to decisional autonomy unless an adherent's will is interfered with through coercion or manipulation. A zero-sum-benefit to adherents of another religion, on its own, is unlikely to amount to such interference.

A second objection might be that even though non-zero-sum benefits to adherents of one religion do not materially burden non-adherence of that religion, might they not burden it expressively? ${ }^{87}$ Does not the establishment of Buddhism, for example, as the state religion express the state's recognition of its superiority over other religions? It is true that non-zerosum benefits to religious adherence may well entail such expressive messages. However, legal recognition that religious freedom can be infringed by expressive harm alone would be destructive of the guarantee of religious freedom itself. Such recognition would undermine the religious freedom of non-adherents to freely criticise, reject, and even condemn the religions they do not adhere to. After all, as we have seen, a capacious understanding of religious freedom founded upon the importance of decisional autonomy, protects adherence as well as non-adherence. Just as it protects the intense as well as the relaxed adherent, it must also protect the tolerant as well as the incensed non-adherent. Comparable to the difficulty with horizontal

\footnotetext{
${ }^{86}$ See Burwell v. Hobby Lobby, 134 S. Ct. 2751 (2014). The Eur. Ct. H.R. in Eweida applied it as a claim against a large corporation - this may well be justified, but it needs cogent reasons that the court failed to provide: see Eweida v. United Kingdom, 57 Eur. H.R. Rep. 8 (2013).

${ }^{87}$ An argument of this type was made by O'Connor J. in Lynch v. Donnelly, 465 U.S. 668 (1984) ('Endorsement sends a message to nonadherents that they are outsiders, not full members of the political community, and an accompanying message to adherents that they are insiders, favored members of the political community') and Sachs J. in S. v. Lawrence 1997 (4) SA 1176 (CC) (S.Afr.) ('negative radiating symbolic effect').
} 
enforcement of religious freedom, recognition of expressive or symbolic harms as burdens on religious adherence could undermine religious freedom itself.

Even if one accepts the argument in the preceding section, could the prohibition on inflicting expressive harm on religious adherence be confined to the state? Surely, the state itself does not have a claim to freedom of religion? That much is true. However, while it is certainly desirable that state officials do not condemn any religion, certain specific religious requirements will frequently come into conflict with state policy or public morality - an across the board prohibition of expressive harms, even when applied to the state alone - is not without problems. This is especially so if one adopts an objective standard for determining expressive harms, i.e. when the symbolic insult to the religion is judged not based on the intention behind the symbolic act, but its public meaning. For this reason, it is best to keep expressive harms outside the remit of what counts as 'burdening' religious adherence. On this understanding, religious establishment, on its own, may well be compatible with religious freedom for all. ${ }^{88}$

On the other hand, benefits to the membership of a religious group to the exclusion of others, whether zero-sum or non-zero-sum, paradigmatically constitute discrimination. While religious adherence needs to be burdened in absolute terms for one's religious freedom to be infringed, members of a religious group need only be disadvantaged comparative to another group for the act to qualify as discriminatory. While there is some debate in discrimination law over whether non-comparative harms to a protected group amount to (prima facie) discrimination, there is no debate over the fact that comparative harms always do. It may be that no employee is entitled to a bonus, but if a company pays a bonus to all its Christian employees but denies it to all others, it would constitute a clear case of discrimination. Discrimination law has also come to register exclusively expressive harms too. ${ }^{89}$

None of this is surprising if we bear the underlying function of discrimination law in mind: to reduce and to ultimately eliminate (pervasive, abiding and substantial) relative group disadvantage. Discrimination law, at its fundamental level, cares for how groups fare relative to each other, in material, political and socio-cultural terms (although, it does so only because that has an absolute impact on the success of the lives of individual members of the relatively disadvantaged group). Thus, non-zero-sum benefits and expressive harms suffice to trigger a discrimination claim.

Each of the three examples of non-zero-sum burdening of adherence we gave abovepilgrimage subsidy, workplace chapels and religious establishment - all of them benefit not just adherence but also group membership. While we argued that none of them-without more - is likely to violate religious freedom, we also think that each of them is a textbook instance of prima facie direct discrimination on the ground of religion. The reason should be obvious - non-zero-sum benefits do not violate religious freedom, but they do discriminate.

\subsection{Overlaps between the Two Rights}

Thus far we have been arguing that the two religion rights - religious freedom and freedom from religious discrimination - are distinct human rights and, as such, protect distinct human interests and distinct (although sometimes overlapping) aspects of religion. Highlighting their distinctiveness does not deny significant overlaps in their scope. The table below illustrates how these rights protect distinct aspects of religion.

\footnotetext{
${ }^{88}$ See Rex Ahdar \& Ian Leigh, Is Establishment Consistent with Religious Freedom?, 49 MCGILL L. J. 635 (2004).

${ }^{89}$ See Tarunabh Khaitan, Dignity as an Expressive Norm: Neither Vacuous Nor a Panacea, 32 OXF. J. OF LegAL STUD. 1 (2012).
} 


\begin{tabular}{|c|c|c|c|c|}
\hline & & & Intentional & Unintentional \\
\hline \multirow{4}{*}{$\begin{array}{c}1 . \\
\text { Affecting } \\
\text { adherence }\end{array}$} & \multirow{2}{*}{$\begin{array}{l}\text { 1.1 Non-Zero- } \\
\text { Sum } \\
\text { Benefiting }\end{array}$} & 1.1.1 State & $\mathrm{A} 1(\mathrm{DD} ; \mathrm{RF})^{90}$ & A3 (ID?; RF) ${ }^{91}$ \\
\hline & & 1.1.2 Private & $\mathrm{A} 2(\mathrm{DD} ; \mathrm{RF})^{92}$ & A4 (ID?; RF) $)^{93}$ \\
\hline & \multirow{2}{*}{$\begin{array}{l}\text { 1.2 Burdening } \\
\text { or Zero-Sum- } \\
\text { Benefiting }\end{array}$} & 1.2.1 State & $\mathrm{B} 1(\mathrm{DD} ; \mathrm{RF})^{94}$ & B3 (ID?; RF) ${ }^{95}$ \\
\hline & & 1.2.2 Private & $\mathrm{B} 2(\mathrm{DD} ; \mathrm{RF})^{96}$ & $\mathrm{~B} 4$ (ID?; RF) ${ }^{97}$ \\
\hline \multirow{2}{*}{\multicolumn{2}{|c|}{$\begin{array}{l}\text { 2. Affecting group } \\
\text { membership }\end{array}$}} & 2.1 State & C1 (DD; RF?) ${ }^{98}$ & C3 (ID; RF) ${ }^{99}$ \\
\hline & & 2.2 Private & $\mathrm{C} 2(\mathrm{DD} ; \mathrm{RF})^{100}$ & $\mathrm{C} 4(\mathrm{ID} ; \mathrm{RF})^{101}$ \\
\hline
\end{tabular}

In row 1, we map the various ways in which religious adherence may be interfered with. Row 1.1 tracks non-zero-sum benefits for religious adherence by state and private persons. Row 1.2 captures other forms of interference with religious adherence. Applying what we learnt in Section 5.2, no interference by a private actor amounts to a breach of religious freedom (RF in rows 1.1.2 and 1.2.2). However, such acts - if intentional—would amount to prima facie direct discrimination (DD) if the private actor is one regulated by discrimination law, and may amount to indirect discrimination if the act is unintentional but disproportionately impacts a religious group (ID?). When the actor is the state, the conclusions with regard to discrimination are similar in rows 1.1.1 and 1.2.1.

${ }^{90}$ See, e.g., Lautsi v. Italy, App. No. 30814/06, Eur. Ct. H.R. 2412 (2011), 54 Eur. H.R. Rep. 3 (2012) (cross in public school classroom) and Establishment cases from the United States such as Van Orden v. Perry, 545 U.S. 677 (2005) (public display of Ten Commandments). Here the state provides a non-zero-sum benefit to one religion/group, but not to others.

${ }_{91}$ An example of unintentionally benefiting adherence to a particular religion in a non-zero-sum manner would be a preference in public employment for candidates who know more than one language, assuming that this is likely to benefit Orthodox Jews and Muslims who know Hebrew or Arabic for religious reasons.

${ }^{92}$ Provision of an Anglican chapel at a private workplace would be an example of a non-zero-sum benefit to the adherence of one religion.

${ }^{93}$ A university that has a flexible holiday policy for academic staff would benefit adherence to those religions that require a holiday.

${ }^{94}$ Examples would include state prohibition of the Muslim headscarf or kosher slaughter (shechita).

${ }^{95}$ For examples of unintentional burdening of religious adherence see Employment Division, Department of Human Resources of Oregon v. Smith, 494 U.S. 872 (1990) (a prohibition on the consumption of peyote); R (Ghai) v. Newcastle City Council [2011] QB 591 (a prohibition on the outdoor cremation of a dead body); Alberta v. Hutterian Brethren of Wilson Colony, [2009] 2 S.C.R. 567 (Can.) (a requirement that driver licences include a photo).

${ }^{96}$ E.g., a private employer banning its employees from wearing the Muslim headscarf.

${ }^{97}$ Examples of B4 include a private employer's workplace dress code that prohibits wearing of all head-coverings or jewelry.

${ }^{98}$ E.g., a state that has different classes of citizenship or imposes differential levels of taxes depending on religion.

99 See, e.g., Naeem v. Secretary of State for Justice [2017] UKSC 27 where it was found that Muslim chaplains were at a disadvantage in the pay scale because of their shorter lengths of service (the Prison Service having not employed Muslim chaplains on a salaried basis until 2002).

100 An example here might be an employer who refuses to interview an applicant because they have a Jewish surname.

${ }^{101}$ E.g., a requirement that a high school diploma is needed for higher paid positions, which then results in members of certain religious groups being disqualified at a substantially higher rate than members of other groups (a 'religious' Griggs case: Griggs v. Duke Power Co., 401 U.S. 424 (1971)). 
Although we have suggested that intentional cases of burdening religious adherence in row 1.2, whether by the state or a private person, will be prima facie direct discrimination, one qualification is needed-it is possible to have a case where all forms of religious (non)adherence were burdened. ${ }^{102}$ In such cases, it is possible that there is no direct discrimination. Even in such cases, it is highly unlikely that all forms of religious adherence will be burdened equally - if some forms are burdened disproportionately over others, a prima facie case of indirect discrimination could still be made.

As we know from the preceding section, if the state interferes by providing non-zero-sum benefits for adherence to any particular religion, religious freedom is not violated (RF). The only prima facie breaches of religious freedom in row 1 happen under 1.2.1, where the state interferes either by burdening or by providing a zero-sum benefit for religious adherence.

When the action affects group membership, rather than adherence, in relevant ways (row 2), that is prima facie discriminatory by definition. Of the various possibilities, it is only where the state intentionally discriminates that is it possible that religious freedom may also be breached. Take for example a law that denies voting rights to the members of a certain religious group. Even though being able to vote is (let us assume) not required for adherence to that religion, a directly discriminatory law of such magnitude has clear implications for religious adherence as well. Each category in this table has a distinct example that cannot be placed in any other category. A different way to visualise these overlaps is through the following diagram:

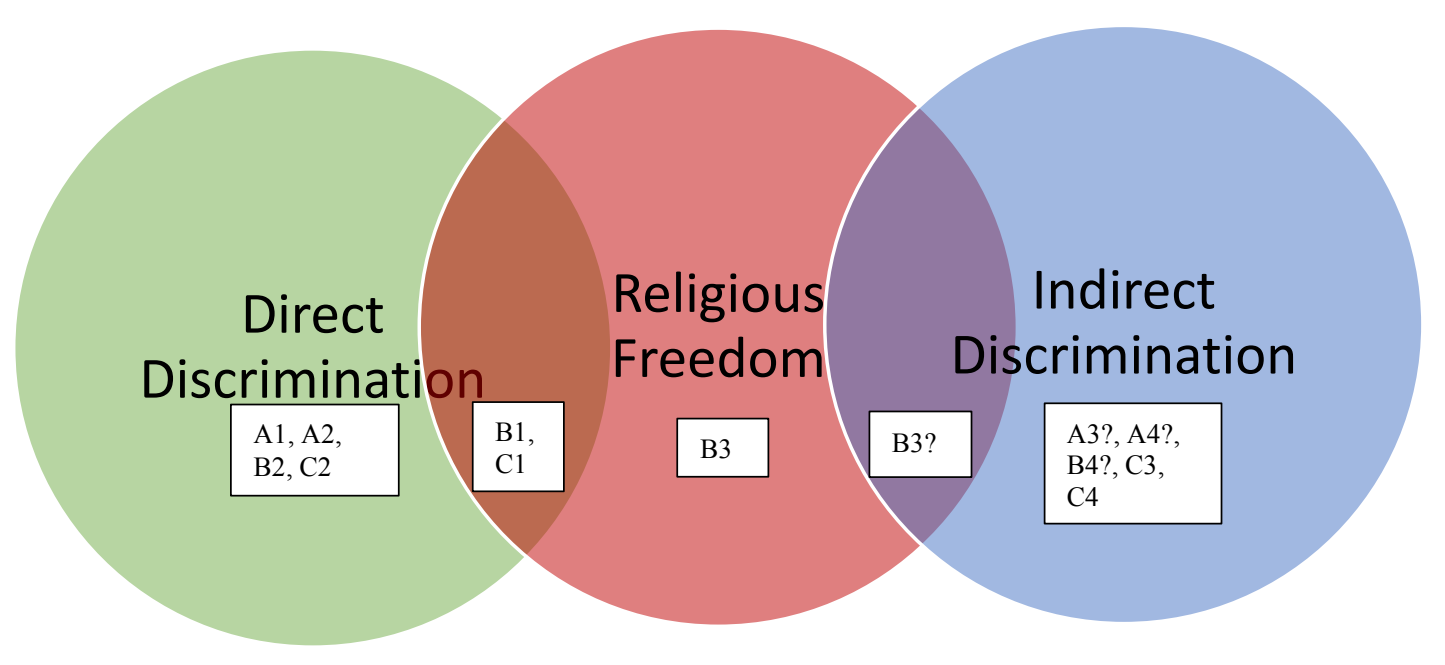

We know that direct discrimination and indirect discrimination are mutually exclusive. Cases that amount to prima facie direct discrimination but do not engage religious freedom (green part of the first circle on the left) include A1, A2, B2 and C2. Cases that are prima facie indirect discrimination but not a prima facie breach of religious freedom (light blue part of the circle on the right) include $\mathrm{C} 3$ and $\mathrm{C} 4$, and potentially $\mathrm{A} 3, \mathrm{~A} 4$ and $\mathrm{B} 4$ (depending on whether the disproportionate impact standard is satisfied). Possible overlap between direct discrimination and religious freedom occurs in cases such as $\mathrm{B} 1$ and $\mathrm{C} 1$; whereas possible overlaps between

${ }^{102}$ Achbita v. G4S Secure Solutions NV (2017) Case C-157/15 (E.C.J.) was arguably one such case. For a critique of the decision see Lucy Vickers, Achbita and Bougnaoui: One Step Forward and Two Steps Back for Religious Diversity in the Workplace, 8 EUR. LAB. L. J. 232 (2017). 
indirect discrimination and religious freedom includes cases under B3. B3 cases that fail to satisfy the disproportionate impact standard of indirect discrimination liability constitute the residual red part of the middle circle.

We have explained how the two religion rights - religious freedom and freedom from religious discrimination - are distinct human rights that protect distinct human interests and distinct aspects of religion. These aspects of religion can, of course, overlap but we have illustrated in the table and diagram above how there remain distinct areas with no overlap.

Given that these two rights protect distinct human interests and distinct aspects of religion, whether and how their infringement may be justified can differ. Both rights under consideration-freedom of religion and the right against religious discrimination-are qualified rights that admit to the possibility of justification. ${ }^{103}$ This is not unusual as few human rights are absolute. Most tend to be qualified rights, in the sense that their infringement may occasionally be justified for sufficiently weighty countervailing reasons. Different jurisdictions characterize the justification analysis differently (with proportionality being the most popular analytic frame). Most, however, consider factors such as the weight of and impact on the interests/rights of both parties and the public interest involved, the nexus between the impugned act and the end it seeks to achieve, and the judiciary's relative institutional capacity and expertise in second-guessing the political decision under challenge. Given our position on relationality - that the right against religious discrimination is only a limited claim between private persons and that the right to religious freedom is a liberty, not a claim, in private contexts - the comments in this section apply only to the justification of state action that infringes upon either of the two rights.

We turn first to infringement of the right against religious discrimination. When a claimant has made a prima facie case of religious discrimination, the intensity of judicial scrutiny is typically very high. ${ }^{104}$ This is because religious group membership is not only normatively irrelevant to most state actions, it is also descriptively irrelevant. In other words, not only should the state not act based on a person's membership of a religious group when it adversely affects vulnerable groups, religious group membership is rarely connected rationally with any legitimate state goal. In fact, its entanglement with state action often reflects prejudice against, hostility towards, stereotyping of, or indifference to the needs of religious minorities. Direct and even indirect discrimination often (although not necessarily) capture these impulses. ${ }^{105}$ This is why a presumptive judicial suspicion of prima facie cases of religious (and, indeed, other forms of) discrimination is justified. It is true that the use of religious group membership as a basis for state action may be justified even outside the context of affirmative actionhowever, such cases will be rare for direct religious discrimination.

In indirect discrimination cases, where a neutral action disproportionately affects a religious group, ${ }^{106}$ the possibility of justification is likely to depend on contextual factors that usually

\footnotetext{
${ }^{103}$ It is true that in statutory contexts governing private relationships, certain forms of discrimination are treated as not justifiable. But in constitutional law, the right against discrimination almost always admits to the possibility of justification, even though sometimes the threshold for realizing that possibility might be extremely high.

${ }^{104}$ In keeping with the practice of most jurisdictions outside the United States, we are assuming that affirmative action measures do not constitute prima facie discrimination. See generally, KHAITAN, supra note 25, at ch. 8.

${ }_{105}$ See Sophia Moreau, The Moral Seriousness of Indirect Discrimination, in Foundations OF InDIRECT DisCRIMINATION LAw (Hugh Collins \& Tarunabh Khaitan eds., 2018). See also Sandy Steel \& Tarunabh Khaitan, Wrongs, Group Disadvantage and the Legitimacy of Indirect Discrimination Law, in FOUNDATIONS OF INDIRECT DisCRIMINATION LAW (Hugh Collins \& Tarunabh Khaitan eds., 2018).

${ }^{106} \mathrm{We}$ are assuming that these neutral rules are not motivated by prejudice or hostility. Such rules would be little more than a pretext for direct discrimination and will be treated by the courts as such.
} 
inform the proportionality analysis (such as the respective weight of the state's and the claimant's interests and the extent to which they are harmed or served by the proposed action). The non-committal interest in not having one's religious group suffer disadvantage is readily cognizable by courts - it is the sort of thing that a public judicial perspective can grasp and evaluate alongside the interests of the state and any third parties.

Determining the justifiability of an act that infringes upon religious freedom, on the other hand, is generally more difficult. The degree of difficulty will vary depending on whether the two rights overlap. Admittedly, some cases are easy. Often religious freedom is violated because of prejudice against, or hostility towards, a particular religion. Such tainted cases will be unjustified even under the most deferential judicial scrutiny, and in any case are also likely to amount to unjustified direct religious discrimination. In fact, the problem of the appropriate standard of review for religious freedom cases does not matter, at least in practical terms, for all overlap cases where both rights are engaged. Wherever we peg the judicial standard of review for religious freedom cases generally, it is unlikely to be higher than the very high standard of review in discrimination cases. In overlap cases, therefore, if religious discrimination is justified, any breach of religious freedom is always going to be justified as well.

Difficulty arises in those cases where the two rights do not overlap-i.e. where religious freedom is engaged, but there is no prima facie case of religious discrimination. As we saw in the preceding sections, such cases are likely to involve neutral rules that burden religious adherence, but do not amount to a disproportionate impact on a religious group (and, therefore, do not constitute prima facie indirect discrimination). ${ }^{107}$ In such cases, it is very difficult for an institution like the judiciary to appropriately balance the publicly intelligible interests of the state (such as its interest in photo driver licences or in prohibiting open air cremations) and third parties (such as a gay couple seeking rental accommodation) with the committed interest of religious adherents (such as those with a religious objection to being photographed, a religious requirement that they be cremated in the open, or a religious disapproval of gay relationships). A court committed to religious freedom, on our account, cannot adopt the committed perspective of the adherent itself (were such adoption even possible) — doing so, we know now, is inimical to religious freedom itself. Without the benefit of this committed perspective, however, the court cannot judge the weight or the intensity of the adherent's interests involved. All it can do is check whether the religious freedom claim is plausible, sincere, and accompanied by other rights claims (such as freedoms of expression, movement, association, conscience, privacy and so on). When these other rights are also involved, the claim will usually be weightier, but only because of the involvement of these other rights. In short, with respect to religious freedom itself, a court has little choice but to adopt a relatively hands-off approach towards the impugned decision. The result is that religious freedom claims, when not accompanied by a discrimination claim, have difficulty in succeeding.

Thus, in a case where (i) religious freedom is infringed by a general law, (ii) not motivated by any animus against a particular religion, (iii) which does not simultaneously constitute a prima facie case of direct or indirect discrimination, (iv) where significant non-committal interests of the public or of third parties are involved, ${ }^{108}$ and $(\mathrm{v})$ where the claimant's other protected freedoms (of expression etc.) do not demand otherwise, a court should adopt a light-touch deferential review of state action. This is an inevitable consequence of the very vast,

\footnotetext{
107 Justice Sedley found that a neutral ban on all jewelry in Eweida was one such case - it did infringe upon religious freedom of a worker who wanted to wear a cross, but did not amount to a disproportionate impact on Christians as a group: Eweida v. British Airways Plc. [2010] EWCA Civ 80.

108 See Siegel, supra note 71.
} 
subjectively-determined, and unpredictable scope of the right to religious freedom - a right that (unavoidably) casts its net so wide must have a shallow bite for the political state to remain functional. We also note that a light-touch approach is not the same as a hands-off approach. Even in these cases, there might be reasons for judicial intervention. After all, while courts cannot weight or appreciate the subjective religious interest of the adherent, they can and must recognize that the subjective interest is a species of the important general interest we all have in our decisional autonomy in matters of religious adherence.

\section{Conclusion}

We have shown that we have two distinct interests when it comes to matters of religion: an interest in our ability to (not) adhere to our religious commitments, and a separate interest in ensuring that our religious group does not suffer relative socio-cultural, political or material disabilities in comparison with other religious groups. The protection of these distinct interests is the primary concern respectively of the right to freedom of religion and the right against religious discrimination. Consequently, we argue that the scope of the right to freedom of religion is extremely wide, whereas that of the right against religious discrimination is relatively narrow. However, we say, the former right should only be available against the state, whereas it is normatively permissible to apply the antidiscrimination right against some nonstate actors. Furthermore, while religious freedom is not engaged when one religious group receives non-zero-sum benefits, this may well amount to religious discrimination. Finally, we map the areas where the two rights overlap, and cases where only one of the two rights is engaged. This careful parsing of the two rights brings significant clarity to the politically charged debates on these rights relating to religion. 